\title{
What do we know about how the terrestrial multicellular soil fauna reacts to microplastic?
}

\author{
Frederick Büks ${ }^{1}$, Nicolette Loes van Schaik ${ }^{2}$, and Martin Kaupenjohann ${ }^{1}$ \\ ${ }^{1}$ Chair of Soil Science, Dept. of Ecology, Technische Universität Berlin, 10587 Berlin, Germany \\ ${ }^{2}$ Ecohydrology and Landscape Evaluation, Dept. of Ecology, \\ Technische Universität Berlin, 10587 Berlin, Germany \\ Correspondence: Frederick Büks (frederick.bueks@tu-berlin.de)
}

Received: 23 January 2020 - Discussion started: 28 February 2020

Revised: 26 May 2020 - Accepted: 15 June 2020 - Published: 8 July 2020

\begin{abstract}
The ubiquitous accumulation of microplastic (MP) particles across all global ecosystems accompanies their uptake into soil food webs. In this review, we analyzed studies on passive translocation, active ingestion, bioaccumulation and adverse effects within the phylogenetic tree of multicellular soil faunal life. The representativity of these studies for natural soil ecosystems was assessed using data on the type of plastic, the shape, the composition, the concentration and the time of exposure.

Available studies cover a wide range of soil organisms, with emphasis on earthworms, nematodes, springtails, beetles and lugworms, each focused on well-known model organisms. Thus, about $58 \%$ of the studies used inappropriate concentrations or units, whereas $42 \%$ applied MP concentrations similar to amounts in slightly to very heavily polluted soils. In many cases, however, polystyrene microspheres were used, which represent a combination of plastic type and shape that is easily available but does not reflect the main plastic input into soil ecosystems. In turn, MP fibers are strongly underrepresented compared with their high abundance within contaminated soils. A few studies also examined the comminution of macroplastic by the soil fauna. Further properties of plastic such as aging, coating and additives have been insufficiently documented. Despite these limitations, there is a recurring pattern of active intake followed by a population shift within the gut microbiome and adverse effects on motility, growth, metabolism, reproduction and mortality in various combinations, especially at high concentrations and small particle sizes.

For the improvement of future studies, we identified the problems with past experiments, and we recommend that coming studies consider the type, shape, grade of aging, specific concentrations of MP fractions and longterm incubation in both natural and contaminated soils.
\end{abstract}

\section{Introduction}

Imagine a compact plastic cube with a length of almost $2 \mathrm{~km}$ and a weight of $7300000000 \mathrm{t}$ that comprises major percentages by weight of $36 \%$ polyethylene (PE); $21 \%$ polypropylene (PP); $12 \%$ polyvinyl chloride (PVC); and $10 \%$ polyethylene terephthalate (PET), polyurethane (PU) and polystyrene (PS), respectively. This was the accumulated global non-fiber production of the six main plastic types as of 2015, and amounts to $87 \%$ of all-time plastic production. This production has evolved exponentially since the early 1950s from some megatons (Mt) to $8300 \mathrm{Mt}$ as of 2015, with a $260 \mathrm{Mt}$ annual output in 2009 increasing to a $380 \mathrm{Mt}$ output in 2015 (Thompson et al., 2009; Geyer et al., 2017). From the total amount of plastic ever produced, $6300 \mathrm{Mt}$ had become waste as of 2015 ; from this total amount only $21 \%$ was recycled or incinerated, whereas $5000 \mathrm{Mt}$ ended up in landfills and nature (Geyer et al., 2017). As a corollary of production, use and disposal, a certain part of plastic waste is constantly released into the environment via various pathways, but our knowledge about rates of mass flow into global ecosystems is very limited. Based on waste generation in coastal countries, Jambeck et al. (2015) calculated the global plastic input to marine ecosystems to be roughly 4.8 to $12.7 \mathrm{Mt}$ in 2010 . 
Such data on soils are lacking, but Nizzetto et al. (2016) estimated that the load of microplastic (MP) to agricultural sites in Europe is of the same order of magnitude as that in marine environments.

By littering, plastic mulching, the application of sewage sludge, digestates and composts, and windblown dispersal (Bertling et al., 2018; Weithmann et al., 2018; Zhang et al., 2019; Wang et al., 2019a), plastic from our technosphere arrives in soil ecosystems in various forms as large and small fragments, fibers and particles. Due to exposure to UV radiation, mechanical stress and processing by soil organisms, plastic items become weathered and prone to a successive comminution towards the MP size range with increased surface, charge and biofilm cover (Kale et al., 2015; Andrady, 2017). However, the resistance of plastic to metabolization causes a constant accumulation in soils as long as the release rate from human processes is above the very slow rate of degradation.

Due to a lack of monitoring programs, data on MP concentrations in terrestrial soils are rare, and those using weight by weight $(w / w)$ concentrations represent only a small part of the information available compared with item concentrations. In soils with only slightly contaminated conditions, amounts seem to average about $1 \mathrm{mg} \mathrm{kg}^{-1}$ soil dry weight

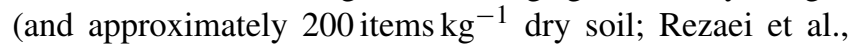
2019). On sites with industrial activity or the intensive use of plastic mulch and sewage sludge for agriculture, concentrations can be increased by 2 to 4 orders of magnitude (Fuller and Gautam, 2016; Zhang and Liu, 2018; Huang et al., 2020). Semisubhydric soils such as beaches, mudflats, mangroves or lagoons, which are additionally contaminated from the aquatic side, contain MP concentrations of the order of 10 100 item $\mathrm{kg}^{-1}$ dry soil, and single extreme samplings have been shown to contain several thousand items (Nor and Obbard, 2014; Naji et al., 2017; Garcés-Ordóñez et al., 2019; $\mathrm{J}$. Li et al., 2018). More informative data using milligrams per kilogram are only available for beaches and coastal deconstruction yards in municipal neighborhoods and amount to 0.5 and $70 \mathrm{mg} \mathrm{kg}^{-1}$ dry soil and $0.00005 \% \mathrm{w} / \mathrm{w}$ and $0.007 \% w / w$, respectively (Reddy et al., 2006; Claessens et al., 2011). All of these concentration data represent a wide range of particle sizes between 0 and $5000 \mu \mathrm{m}$ with different materials, shapes and degrees of aging.

Plastic particles can possibly enter and accumulate in the food web by either direct uptake from soil or by consumption of other soil biota that are contaminated by adhesion or ingestion (Huerta Lwanga et al., 2017a). There is evidence that MP is even incorporated by plants and unicellular organisms at the base of the food web. Bacteria, for example, which are reasonably assumed to avoid MP uptake due to their minor size and the prevalent lack of phagocytosis, have been shown to take up inorganic nanoparticles of a few nanometers in size (Kumar et al., 2011). Although the physiochemical properties of weathered nanoparticulate plastics might differ from these, their uptake also seems likely.
A similar argument can be made for fungi and soil algae, although studies on incorporation are lacking, whereas transfer into a freshwater food web by adhesion of nanoplastic on algae has been shown by Chae et al. (2018). The uptake of MP into plant roots is also inhibited (Rillig et al., 2019), but the permeation of nanoplastics into plant tissue has been reported (Li et al., 2019). However, the integration of MPs into root tissue after adsorption to the rhizodermis has yet to be studied.

In contrast, protozoa feature phagocytosis for the active ingestion of particles. Diverse soil, freshwater and marine ciliates ingest PS/latex beads from 0.1 to $14.4 \mu \mathrm{m}$ in size in laboratory experiments, with a preference for their natural prey size (Fenchel, 1980; Jonsson, 1986; Lavin et al., 1990). Soil amoebas act similarly, but they additionally select according to food quality (Weisman and Korn, 1967; Vogel et al., 1980; Bowers and Olszewski, 1983; Avery et al., 1995; Elloway et al., 2006).

Finally, many soil microbiota live protected within biofilms. Plastic particles have been shown to be a potential surface for the formation of those biofilms (Lobelle and Cunliffe, 2011), which are a food source for grazing primary consumers. Inadvertent ingestion might also transfer occluded or abraded MP to higher trophic levels.

But what about the larger organisms that feed on these free plastic particles, contaminated microorganisms, biofilms and one another? Recent work has discussed the effects of MPs on soil biota (Chae and An, 2018) or has called for intensified research on certain taxonomic groups (Rillig and Bonkowski, 2018). Thus, we were motivated to carry out a review with a focus on the most highly produced plastics and their passive translocation, ingestion, bioaccumulation and adverse effects on the multicellular soil fauna. The types, sizes and shapes of plastic used in former laboratory studies have been compared with the available knowledge on plastic in the environment and recommendations are given for future research. This analysis aims to support the assessment of the influence of MPs on the ecosystem services provided by diverse soil organisms.

\section{Search pattern}

Within the tree of life, edaphic branches were identified comprising taxa that permanently inhabit the soil, taxa that are part of the soil food web and/or burrowing macro- and megafauna, and taxa that have active subterranean larval stages. The resulting tree of soil life based on the NCBI taxonomy database (Fig. 1) was drawn using phyloT software and shows the leading taxonomic rank, which is generally family, although in exceptional cases, e.g., if one species represents the only soil-dwelling stage between many aquatic stages, may be a lower rank.

A pattern of search terms was established (Table 1), consisting of "taxon" (Linné's binominal nomenclature, com- 


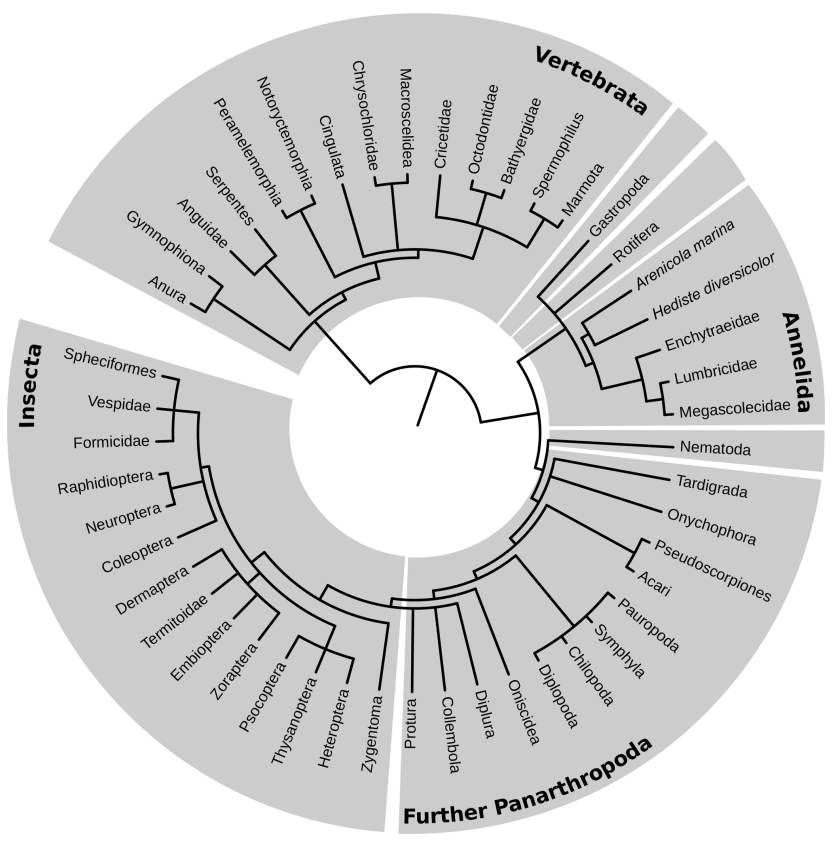

Figure 1. Tree of edaphic fauna. Taxonomic ranks that were examined in this qualitative study are shown on the outer rim of the diagram. The length of the connecting line between two taxa represents the grade of the phylogenetic relationship.

mon name, plural-sensitive search), "plastic type" (plastic, microplastic, nanoplastic, PE or polyethylene, PP or polypropylene, PVC or polyvinyl chloride, PS or polystyrene, PU or polyurethane, PET or polyethylene terephthalate, and latex) and "common shapes" (fragments, particles, fibers, microfibers, beads, microbeads and microspheres). Some type-shape combinations caused problems, as they led to a very large amount of unuseful, off-topic papers, e.g., when using any taxon combined with PET, papers that used PET bottles in their experimental setups or studies on pets were selected. Therefore, these combinations of search terms were excluded from the search pattern. Further plastic types and shapes occurring within the studies that were found were also included in the review. Data on microspheres and microbeads were pooled, as both names describe the same thing.

The search was applied between June 2019 and January 2020 within the Web of Science Core Collection database; it was repeated in the first week of January 2020 and covers publications until January 2020. The search strings' result from the combinations of taxa, plastic types and particle shapes is shown in Table 1. Based on the search pattern, data on passive transport, ingestion, bioaccumulation and adverse effects were collected for each edaphic group. Studies that used uncommon, local, outdated or strange terms or nicknames were excluded by the search pattern. Studies testing injection to tissues, lymph or blood were excluded, as they do not represent natural ways of incorporating MPs.
Data on MP inhalation by megafauna do represent a natural uptake process, but these studies were also excluded as they are exclusively related to aboveground organisms that only occur on the outer edge of the food web. Furthermore, running debates on phylogenetic classifications are not part of this work, and taxonomists will be able to adjust the branches according to their specific purpose.

The data on related taxonomic groups were pooled and evaluated for their environmental representativity based on exposure time, plastic concentrations and the properties used. From this synthesis, recommendations for a structured experimental design were derived for application in future studies.

\section{Data collection}

\subsection{Insects}

Within the Panarthropoda, the insects comprise the highest taxonomic diversity. Moreover, they represent an unevenly studied taxonomic group with respect to MPs.

Within the Insecta, the Coleoptera (beetles) are an extraordinarily diverse and abundant taxon. Studies on plastic uptake by adult individuals have mainly focused on the subfamily Scarabaeinae (dung beetles). Comprehensive experiments with latex microbeads have shown that many species only ingest smaller particles with maximum diameters of about 10$83 \mu \mathrm{m}$ and retain them within the gut - with a slightly positive dependence on body size. Larger particles were rejected by a filtering mechanism within the mouth region and were not ground by the mandibles (Holter, 2000; Holter et al., 2002; Holter and Scholtz, 2005). Beside the information on nematodes, these data comprise the most detailed information (by far) about the size-dependent uptake of MP particles compared with other edaphic taxa. This provides a good foundation for future studies on adverse concentrations. In addition, several studies that have used plastic as the predominant food source have shown chewing, ingestion and intestinal degradation of different PS and PE foams in feeding experiments with Tenebrio sp. larvae (mealworms). These experiments have also pointed out an alteration of the gut microbiome, although no adverse effects on reproduction and survival have been reported - with only one observed case of a nonsignificant tendency toward higher mortality after 1 month of exposure (Yang et al., 2015, 2018; Brandon et al., 2018; Peng et al., 2019).

The Isoptera (termites), which were recently categorized as part of the order Blattodea, are the oldest social insects, with a tribal history of about 130 million years (Korb, 2008). Especially in arid ecosystems that lack earthworms, they play an important role in the homogenization of soils as well as in the sorting of soil mineral particles for building mounds and the decomposition and distribution of organic matter (De Bruyn and Conacher, 1990). Tsunoda et al. (2010) and Lenz et al. (2012) have shown that different termite species are picky feeders and that they erode PE but avoid other plas- 
Table 1. Types and shapes of microplastic particles in edaphon studies within this review. The search on soil biota was carried out based on Linné's systematic names and common names. " $x$ " symbolizes combinations excluded from the search pattern. The number counts show how often type-shape combinations were used in all reviewed experimental setups independently of organism. Empty fields denote zero results. The terms "microbeads" and "microspheres" are often used synonymously and are therefore counted together.

\begin{tabular}{|c|c|c|c|c|c|c|c|c|c|}
\hline & & $\begin{array}{l}\text { Frag- } \\
\text { ments }\end{array}$ & $\begin{array}{l}\text { Par- } \\
\text { ticles }\end{array}$ & Fibers & $\begin{array}{r}\text { Micro- } \\
\text { fibers }\end{array}$ & Beads & $\begin{array}{r}\text { Micro- } \\
\text { beads }\end{array}$ & $\begin{array}{l}\text { Micro- } \\
\text { spheres }\end{array}$ & $\begin{array}{r}\text { Other, } \\
\text { diverse, } \\
\mathrm{NA}\end{array}$ \\
\hline Plastic & $x$ & & & & & & & & \\
\hline \multicolumn{10}{|l|}{ Microplastic } \\
\hline \multicolumn{10}{|l|}{ Nanoplastic } \\
\hline PE or polyethylene & $x$ & 4 & 10 & 1 & 1 & 1 & & & 7 \\
\hline PP or polypropylene & $x$ & 1 & & & & & & & \\
\hline PVC or polyvinyl chloride & $x$ & 4 & 6 & 1 & & & & & \\
\hline PS or polystyrene & $x$ & 6 & 3 & & & & 24 & 4 & \\
\hline PU or polyurethane & $x$ & & & & & & & & \\
\hline PET or polyethylene terephthalate & $x$ & 3 & & 2 & & & $x$ & & \\
\hline Latex & $x$ & & & & $x$ & & 6 & & \\
\hline Other & & 6 & 3 & & 1 & & & 1 & \\
\hline NA & & 1 & & 1 & & 2 & & 3 & \\
\hline
\end{tabular}

NA stands for not available.

tic cable sheathings. This suggests the excretion of ground MP particles by termites, but the metabolic impacts are unknown. In contrast to termites, data on other Blattodea (e.g., cockroaches) were not found.

The suborder Apocrita comprises some flying insects that inhabit burrows within the soil such as ground-dwelling wasps within the Vespidae superfamily, mining bees within the Apoidea superfamily and the Spheciformes. They generally do not prey and feed on subterrestrial organisms, but they may move MP particles into the ground, as implied by a report from Allasino et al. (2019) on solitary bees that built nests made fully of plastic fragments. The Apocrita also contain the Formicidae (ants). Some ant species are considered an important vector for seed dispersal, which is a behavior that could also be shown for artificial plastic seeds with a diameter of $\sim 2 \mathrm{~mm}$ (Hughes and Westoby, 1992; Angotti et al., 2018). Robins and Robins (2011) found that this also includes differently shaped cultural objects: Rhytidoponera metallica, a representative of ground-nesting, omnivorous ants, is not only capable of remarkable bioturbation but also of active, apparently random burying of anthropogenic plastic artifacts $>1 \mathrm{~mm}$. Seeds are used as a food source; thus, the ingestion of plastic bites is conceivable but has not been documented. The uptake of latex microspheres $\geq 0.88 \mu \mathrm{m}$ with liquids by Solenopsis invicta larvae seems to be prevented by filtration within the mouth, and the particles are released as larger aggregates, whereas other species ingest much larger particles up to $150 \mu \mathrm{m}$ (Glancey et al., 1981). However, also here, data on adverse effects are missing.

Further insects with edaphic adult stages such as Dermaptera (earwigs), Heteroptera (true bugs) and Zygentoma (silverfish, fish moth and firebrat) or soil- or litter- dwelling larvae such as Embioptera (webspinners or footspinners), Thysanoptera (thrips), Psocoptera (booklice, barklice or barkflies), Neuroptera (lacewings), Raphidioptera (snakeflies) or Zoraptera (angel insects) have not yet been researched with a focus on soil MPs.

Regarding insects, mainly studies on the translocation and uptake of MP have been carried out. In contrast, work on bioaccumulation is completely lacking, and adverse effects have been sparsely tested using Tenebrio sp. larvae. Such studies could provide information on whether or not the input of MPs in soil ecosystems is one of many factors causing the global decline in entomofauna (Oliveira et al., 2019; Sánchez-Bayo and Wyckhuys, 2019).

\subsection{Other panarthropods}

Apart from the insects, Acari (mites) comprise many abundant soil-dwelling taxa that feed on litter, fungi and fauna as both predators and parasites; they are also bioindicators, as they are sensitive to changes in the soil physiochemical environment (Gulvik, 2007). Experiments have indicated that mites passively transport MPs by pushing and dragging after attachment to their cuticle, as shown with $80-250 \mu \mathrm{m}$ sized PVC particles in a Petri dish experiment without soil (Zhu et al., 2018a). The population within manure pats slightly declines when exposed to millimeter-sized, unweathered PE and PS particles at concentrations of $5 \% v / v$ and declines strongly at $\geq 60 \% v / v$ (Stamatiadis and Dindal, 1990). This may be an effect of moisture deficiency due to a reduced water-holding capacity in an unnaturally enriched substrate but not necessarily due to plastic intake. In contrast, no data 


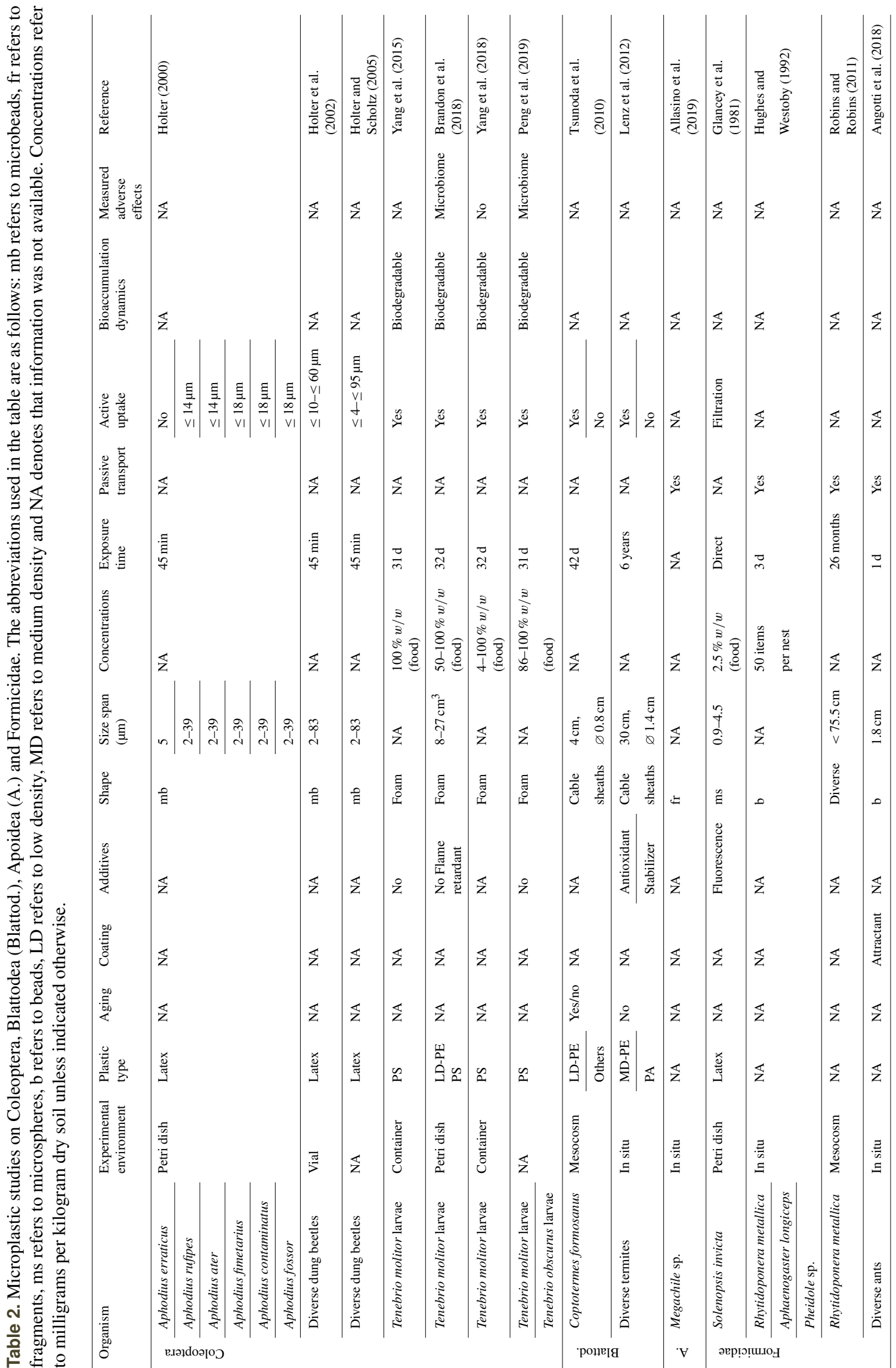


were found on their arachnoid, predatory relatives, Pseudoscorpiones (false scorpions).

Similar to many other highly abundant and diverse representatives of the soil mesofauna, the Oniscidea (woodlice) contribute to the decomposition of litter via chewing and passage through their digestive system (Warburg, 1987) and react strongly to environmental pollution; thus, they can potentially be used as bioindicators (van Gestel et al., 2018). They practice a strict selection of natural food sources (Hassall and Rushton, 1984). This is also demonstrated for starchand cellulose-based plastic films $\left(4 \mathrm{~cm}^{2}\right)$, which were consumed and digested in experiments using the model organism Porcellio scaber, in contrast to PHB (polyhydroxybutyrate) films, which reduce the feeding rate (Wood and Zimmer, 2014). Smaller PE particles $(137 \pm 51 \mu \mathrm{m}$ and $183 \pm 93 \mu \mathrm{m})$ embedded in food pellets $(0.4 \% \mathrm{w} / \mathrm{w})$ were taken up easily by Porcellio scaber, and the smaller fraction caused a slight, nonsignificant reduction of body mass after $14 \mathrm{~d}$ of exposure, but there was no observed impact on feeding, defecation or energy reserves (Kokalj et al., 2018).

Other panarthropodean groups are even less studied in terms of MPs. We did not find literature on the subphylum of Myriapoda, containing the Diplopoda (millipedes), Chilopoda (centipedes), Pauropoda and Symphyla (pseudocentipedes or symphilids) classes, which are important litterfeeders and predators within various soil ecosystems.

The situation is similar for the Tardigrada (water bears or tardigrades) phylum, which comprises many ecologically relevant and well-studied species that feed on microorganisms and detritus particles. Sparse field research in semisubhydric environments has shown no uptake of MP fibers by Tardigrada (Gusmão et al., 2016); however, comprehensive data on terrestrial soils are lacking. This is similar for the related phylum of Onychophora (velvet worms), primordial invertebrates that are mainly native in litter and soils with high water-holding capacity under Pleistocene-like forest vegetation within tropical and moderate regions (Monge-Nájera, 1994).

The phylum of Collembola (springtails), together with the orders of Diplura and Protura (Westheide and Rieger, 1996; Pass and Szucsich, 2011), are intensively studied morphological groups that exhibit similar ecological functions, such as the distribution and decomposition of organic matter as well as the control of fungal abundance (Hopkin, 1997). Springtails provide up to $27 \%$ of the soil biomass and up to $33 \%$ of the total soil respiration (with higher shares in colder ecosystems; Petersen, 1994) and can be present in numbers of up to 100000 individuals per square meter (Hopkin, 1997). Thus, their well-being plays an important role in ecosystem functioning.

In a Petri dish experiment without soil, Maaß et al. (2017) showed the passive transport of urea-formaldehyde particles $<400 \mu \mathrm{m}$ and undefined PET fragments by two Collembola species (Folsomia candida and Proisotoma minuta) due to attachment, but they found no ingestion. Within a soil ma- trix, the trials carried out by Kim and An (2019) indicated a hindrance of collembolan migration by larger PS particles $(44 \pm 39,282 \pm 131$ and $676 \pm 479 \mu \mathrm{m})$ at concentrations of $1000 \mathrm{mg} \mathrm{kg}^{-1}$, corresponding to highly contaminated soils. In addition, they even found suppressed mobility due to the attachment of smaller PS microbeads $(0.47-0.53 \mu \mathrm{m})$ at concentrations of $8 \mathrm{mg} \mathrm{kg}^{-1}$ dry soil, which is equivalent to the values found in nature. Small particles $(<50 \mu \mathrm{m})$ were moved, whereas larger particles were most likely cast off. When $F$. candida encounters two of its predators, the mites Damaeus exspinosus and Hypoaspis aculeifer, the dispersal of $80-250 \mu \mathrm{m}$ PVC particles is enhanced, as shown by Zhu et al. (2018a) in a Petri dish experiment. Without proving ingestion or the minimal effective MP concentration, Zhu et al. (2018b) reported alteration of the gut microbiome and adverse effects on the growth and reproduction of $F$. candida by $80-250 \mu \mathrm{m}$ PVC particles mixed in soil at concentrations of $1000 \mathrm{mg} \mathrm{kg}^{-1}$ dry soil. These data were not considered robust (van Gestel and Selonen, 2018), but they concur with a later study that found inhibited reproduction at $\geq 1000 \mathrm{mg} \mathrm{kg}^{-1}$ and avoidance behavior as well as microbiome alteration at $\geq 5000 \mathrm{mg} \mathrm{kg}^{-1}$ (Ju et al., 2019). Such concentrations can occur in highly contaminated soils (Fuller and Gautam, 2016). However, documentation on the active uptake, gnawing and grinding of MPs by springtails proposed by Rillig (2012) is still lacking; furthermore, no studies on Diplura and Protura were found.

\subsection{Annelida}

Land-based Annelida comprise another large group of invertebrates. The Lumbricidae (earthworms) are a well-studied family (Darwin, 1881; Lavelle et al., 2006) that is represented in high abundance and diversity in many ecosystems all around the world (Phillips et al., 2019). Earthworms are often used as indicators of soil health (Fründ et al., 2011; Pulleman et al., 2012), as they are ecosystem engineers that, through their burrowing activity, influence various soil physical, chemical and biological processes (Jouquet et al., 2006; Lavelle et al., 2006).

The vast majority of studies on the influence of MPs on earthworms are performed using PE and the species Lumbricus terrestris or Eisenia fetida, but individual studies have also been carried out using Aporrectodea rosea (Boots et al., 2019) and Eisenia andrei (Rodriguez-Seijo et al., 2017) or the less common species Metaphire californica (H.-T. Wang et al., 2019). We found one field study on earthworms and MPs (Huerta Lwanga et al., 2017a) among many laboratory experiments with MPs mixed into soil volumes (concentrations ranging up to $20000 \mathrm{mg} \mathrm{kg}^{-1}$ dry soil) or applied with litter on top of the soil surface $(\leq 60 \% w / w)$. The particles sizes were usually $<1 \mathrm{~mm}$ in diameter, although some were even up to $2 \mathrm{~cm} \times 2 \mathrm{~cm}$, and the duration of experiments was generally from 14 to $28 \mathrm{~d}$, although a few lasted up to $60 \mathrm{~d}$. 


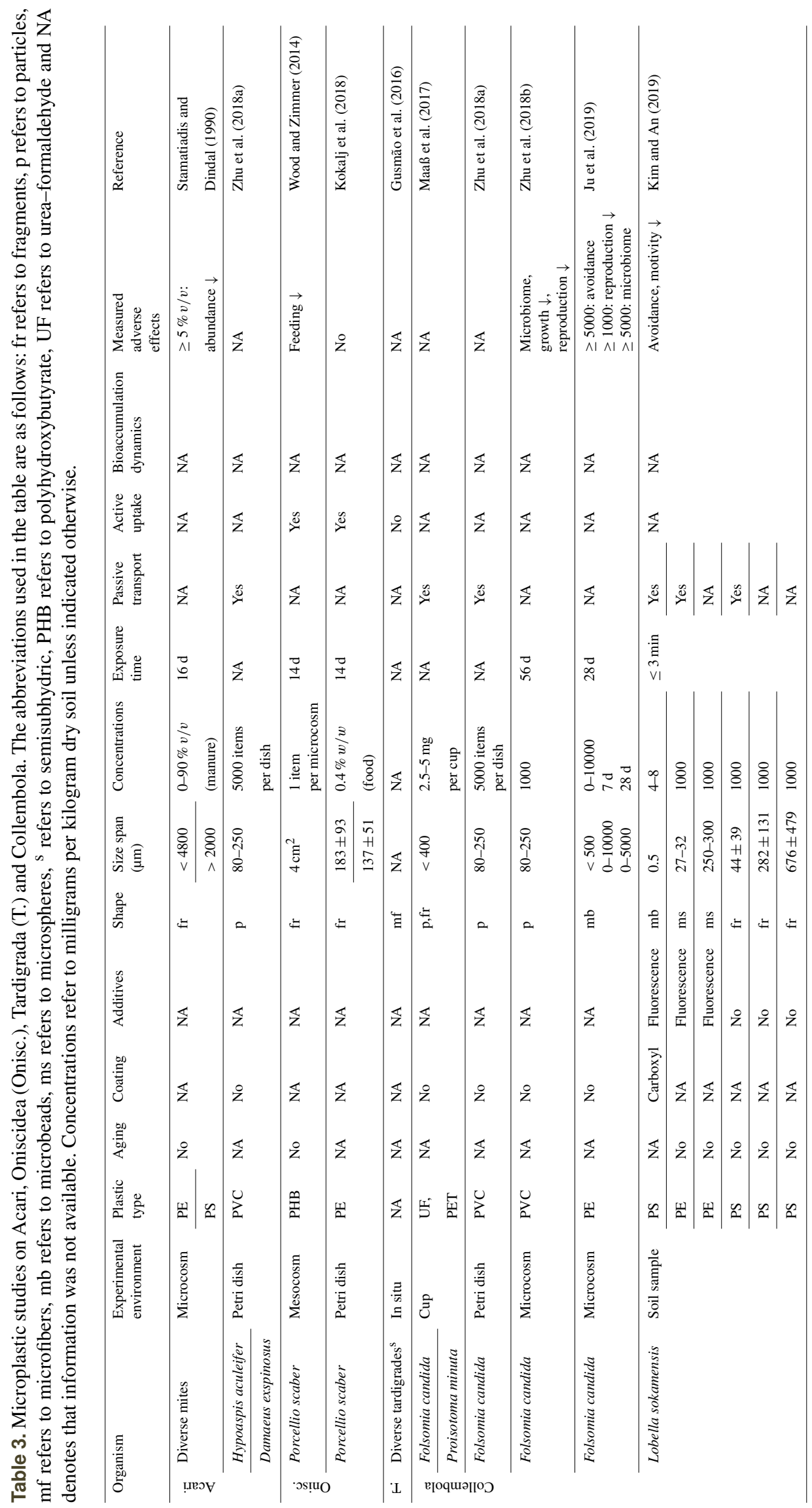


The uptake of a broad size range of MPs by earthworms has been shown in studies based on particles in earthworm casts of Lumbricus terrestris (Huerta Lwanga et al., 2016; Cao et al., 2017; Hodson et al., 2017; Rillig et al., 2017; Prendergast-Miller et al., 2019; Yu et al., 2019; Huerta Lwanga et al., 2017a), Eisenia fetida (Rodríguez-Seijo et al., 2018; Chen et al., 2020; Wang et al., 2019b), Eisenia andrei (Rodriguez-Seijo et al., 2017) and Metaphire californica (H.-T. Wang et al., 2019). Zhang et al. (2018) showed that relatively large PE particles of $1.5 \mathrm{~cm} \times 1.5 \mathrm{~cm}$ are not ingested by Lumbricus terrestris, but partial ingestion of such large particles of biodegradable MPs does take place after initial weathering in soil or in compost has occurred. In some laboratory experiments, MPs were found in the gut of dissected earthworms (Huerta Lwanga et al., 2016; Hodson et al., 2017; Rodriguez-Seijo et al., 2017), but the concentration of MPs in the gut was not significantly different between treatments nor significantly different from the bulk soil concentration; thus, there was no evidence of accumulation of MPs in the earthworm bodies (Hodson et al., 2017). Chen et al. (2020) assumed that an accumulation of MP takes place in Eisenia fetida based on an observed increase in MP concentrations in casts over the course of 4 weeks. Huerta Lwanga et al. (2017a) supposed an accumulation of MPs in the food chain as the concentration of MPs in chicken gizzards is strongly enhanced compared with that in the earthworm casts in the same experiments. However, it was mainly the amount of large particles, i.e., macroplastics, in the gizzards that was enhanced; thus, it seems more likely that the chickens directly fed on plastics, and an accumulation through the food chain cannot be proven given the current knowledge. Hence, this requires further investigation.

Several studies did not find significant negative effects of MPs on earthworms' avoidance behavior (Judy et al., 2019) nor on growth (Hodson et al., 2017; Rodriguez-Seijo et al., 2017; Judy et al., 2019; Wang et al., 2019b), mortality (Hodson et al., 2017; Rillig et al., 2017; Rodriguez-Seijo et al., 2017; Judy et al., 2019; Prendergast-Miller et al., 2019) or reproduction (Huerta Lwanga et al., 2016; RodriguezSeijo et al., 2017). However, other studies have shown adverse effects due to the uptake of MPs to different degrees and on different aspects of earthworms' fitness: reduced growth was shown by Cao et al. (2017) for Eisenia Fetida, and mortality increased at an exposure to MP concentrations of $\geq 10000 \mathrm{mg} \mathrm{kg}^{-1}$ dry soil. At lower concentrations, no significant effects were found. The growth of Aporrectodea rosea was also inhibited when exposed to biodegradable polylactic acid, which is a conventional high-density polyethylene (at $1000 \mathrm{mg} \mathrm{kg}^{-1}$ dry soil), and MP clothing fibers (at $10 \mathrm{mg} \mathrm{kg}^{-1}$ dry soil; Boots et al., 2019). Huerta Lwanga et al. (2016) showed a decrease in growth and increased mortality at concentrations of $\geq 28 \% \mathrm{w} / \mathrm{w}$ in litter after $60 \mathrm{~d}$, although after just $14 \mathrm{~d}$ no mortality occurred in these experiments.
In some studies, additional effects such as histopathological changes or stress biomarkers were measured. For Eisenia fetida, Chen et al. (2020) observed skin damage at MP concentrations of $1500 \mathrm{mg} \mathrm{kg}^{-1}$ in soil, measured an increase in catalase activity and malondialdehyde content at $1000 \mathrm{mg} \mathrm{kg}^{-1}$, and at $\geq 1000 \mathrm{mg} \mathrm{kg}^{-1}$ acetylcholine esterase was significantly stimulated. Wang et al. (2019b) tested Eisenia fetida and found that MPs only increased the catalase and peroxidase levels as well as the level of lipid peroxidation, whereas they decreased the activity of superoxide dismutase and glutathione S-transferase at an exposure of $200000 \mathrm{mg} \mathrm{kg}^{-1}$ dry soil for $14 \mathrm{~d}$. No discernible influence was found at $100000 \mathrm{mg} \mathrm{kg}^{-1}$. However, Rodríguez-Seijo et al. (2018) also found a significant positive correlation between the MP concentration and different biomarker responses for Eisenia fetida: catalase, glutathione S-transferase, lactate dehydrogenase and thiobarbituric acid reactive substances. In addition, Rodriguez-Seijo et al. (2017) observed histological damage of the gut and the occurrence of inflammatory processes as well as an increase in stress response indicators associated with MP exposure in Eisenia andrei. For Lumbricus terrestris, PrendergastMiller et al. (2019) showed an increase in metallothionein expression after exposure to an MP concentration of $\geq$ $1000 \mathrm{mg} \mathrm{kg}^{-1}$ dry soil and a decrease in heat shock protein 70 at a concentration of $\geq 10000 \mathrm{mg} \mathrm{kg}^{-1}$.

Due to the large differences in the experimental conditions, e.g., the size of the MPs, the addition of MPs to soil or to litter, the duration of experiments and the earthworm species, the current knowledge is not sufficient to detect the existence of a threshold MP size or concentration at which MPs become harmful for earthworms or how this threshold differs for different earthworms species and MP shapes. The results of Huerta Lwanga et al. (2016), who found no effects of MPs on earthworms after $14 \mathrm{~d}$ but a significant influence on growth and mortality after $60 \mathrm{~d}$, indicate the importance of longer measurement periods. This is consistent with Pelosi et al. (2015), who concluded that the influence of pesticides on earthworm communities should be tested in long-term field experiments.

Earthworms' activity also increased the transport of MPs in soil columns to deeper soil layers (Rillig et al., 2017; Yu et al., 2019; Huerta Lwanga et al., 2017b); the smaller the MP, the stronger the transport. Particles are transported both actively - ingested and later cast out - and passively after attachment to the earthworm's body or by water flow through the biopores. As Huerta Lwanga et al. (2018) showed that the bacteria in the gut of Lumbricus terrestris can decompose MPs, it seems likely that particles taken up at the surface are egested as smaller particles in deeper layers.

MPs might well serve as a vector for contaminant transport to soil organisms. Although adsorption on plastics was seen to be lower than on the soil matrix, the desorption of $\mathrm{Zn}$ was observed to be higher in synthetic earthworm guts. However, there was no measurable negative effect of $\mathrm{Zn}$ or 
PE on Lumbricus terrestris (Hodson et al., 2017). H.-T. Wang et al. (2019) studied the influence of MPs on arsenic uptake and the associated negative effects on Metaphire californica and concluded that MPs decreased the uptake of arsenic and reduced the influence of arsenic on the gut bacterial communities. Rodríguez-Seijo et al. (2019) showed altered enzyme activities and enhanced avoidance behavior in the face of low-density PE (LD-PE) pellets spiked with the insecticide chlorpyriphos. X. Yang et al. (2019) studied the influence of MPs on the transport of glyphosate; however, they mainly showed that the glyphosate transport was increased by earthworm activity, although the role of MPs in this transport could not be determined in their study. These studies show that MPs might have very different influences on the uptake and adverse effects of different pollutants on earthworms, and further investigation is needed in order to understand the influence of MPs on pollutant transport.

In contrast to the recently well-researched Lumbricidae, a near-relative, the family of Megascolecidae (giant earthworms), has not yet been mentioned in literature. Another branch within the Annelida, the small Enchytraeidae (potworms), have been shown to suffer adverse impacts on body weight and microbiome due to PS microspheres $(0.05-0.1 \mu \mathrm{m})$ within their food source at concentrations of $\geq 10 \% \mathrm{w} / \mathrm{w}$, but an unexpected increase in reproduction at $0.5 \% w / w$ has also been reported (Zhu et al., 2018). Reproduction was reduced at abnormal concentrations of $90 \mathrm{~g} \mathrm{~kg}^{-1}$ dry soil of polyamide particles (13 to $150 \mu \mathrm{m}$ ) but not with PVC (Lahive et al., 2019).

The edaphon of semisubhydric soils is often treated as a marginal group between the respective areas of interest of soil and aquatic scientists. Although a highly diverse soil biocenosis is outside the focus of this paper, the benthos along seashores and fresh waters is also affected by MPs; therefore, it should briefly be mentioned by reviewing the lugworm Arenicola marina, a well examined deposit-feeder of the tidal flats. In situ, MP accumulates within its tissue and feces (Van Cauwenberghe et al., 2015). In laboratory experiments, PS particles $\geq 500 \mu \mathrm{m}$ were avoided as a food source and were passively translocated within the sediment at concentrations of $\sim 2 \mathrm{~g} \mathrm{~kg}^{-1}$ (Gebhardt and Forster, 2018); however, these particles were measured within the feces at $\sim 74 \mathrm{~g} \mathrm{~kg}^{-1}$, effecting feeding activity and body weight but showing no influence on the survival rate (Besseling et al., 2012). PS microspheres $\leq 30 \mu \mathrm{m}$ remained within the animal without any adverse effects regardless of particle size (Van Cauwenberghe et al., 2015). Other studies have found adverse effects on respiration, energy reserves, feeding, egestion and casting following the uptake of PVC particles $\leq 478 \mu \mathrm{m}$ at different sediment concentrations of $>2 \mathrm{~g} \mathrm{~kg}^{-1}$, although no effect on biomass or survival has been reported due to HD-PE (Wright et al., 2013; Green et al., 2016). There is further difficulty in distinguishing between the adverse effects of MPs and substances adsorbed on or leached from MPs (Besseling et al., 2012). When adding PCB-spiked PE to mud flat sediment at concentrations of up to $5000 \mathrm{mg} \mathrm{kg}^{-1}$ dry mass, there was no significant change in the survival rate or body weight. The decreased feeding activity and heap mass could be attributed to increasing plastic concentrations but not to enhanced PCB bioaccumulation via PE uptake (Besseling et al., 2017). However, all of these studies found adverse effects at MP concentrations that were orders of magnitude above natural values.

\subsection{Further invertebrates}

As part of the microfauna, the phylum Nematoda (nematodes or roundworms) is an ecologically important branch containing > 25000 species (Zhang, 2013) in freshwater, marine, endobiotic and soil habitats. Due to their diverse trophic interactions nematodes hold a central position in both bottomup and top-down controlled food webs (Yeates, 2001; Ferris, 2010) and, thus, most likely the uptake and transfer of MPs.

Active feeding of adults and larvae of different species on $0.5-6 \mu \mathrm{m}$ PS/latex microspheres (the size of their bacterial prey) has been proven by Nika et al. (2016) and Fueser et al. (2019). However, most MP experiments on Nematodes are based on the bacterial-feeding model organism Caenorhabditis elegans. Kiyama et al. (2012) showed the favored uptake of PS microspheres with sizes from 0.5 to $3 \mu \mathrm{m}$ by adult and $0.5 \mu \mathrm{m}$ by larval $C$. elegans. The ingestion of MPs decreased in the presence of bacteria as the natural food source.

When larval stages and adults ingested PS between 0.05 and $5 \mu \mathrm{m}$ within an aqueous suspension or on agar plates, adverse effects such as oxidative stress, neurodegeneration, intestinal and DNA damage, or dysfunction in motility, growth, life span, defecation, reproduction or energy metabolism appeared over a wide spectrum of concentrations from $\geq 1 \mu \mathrm{g} \mathrm{L}^{-1}$ up to $\geq 86.3 \mathrm{mgL}^{-1}$ (Zhao et al., 2017; Dong et al., 2018; Kim et al., 2019; Lei et al., 2018a, b; Qu et al., 2019a). These effects are not seen below $1 \mu \mathrm{g} \mathrm{L}^{-1}$ (Qu et al., 2019b), and they are enhanced due to amino modifications on microsphere surfaces (Qu et al., 2019c). The incubation on agar plates with PE, PP and PVC particles $<70 \mu \mathrm{m}$ caused similar influences on survival, fertility, brood size and intestinal function (Lei et al., 2018b). Leachates from soils amended with $5 \mathrm{mg} \mathrm{kg}^{-1}$ dry soil of high-density PE (HD$\mathrm{PE}$ ) and PVC decreased reproduction in laboratory cultures, but there was no effect shown on survival after the application of PET (Judy et al., 2019). Furthermore, silica nanoparticles $(0.05 \mu \mathrm{m})$ are not only taken up orally but also via the vulva and spermathecae, and they migrate into gonad cells (Scharf et al., 2013). This process was confirmed for PS nanoparticles with the potential of a transfer to the progeny (Zhao et al., 2017).

The clear adverse effects of these studies are limited in their representativity by a narrow restriction to liquid cultures and a single model organism. Broader studies like on prominent soil-dwelling nematodes such as Acrobeloides buetschlii 

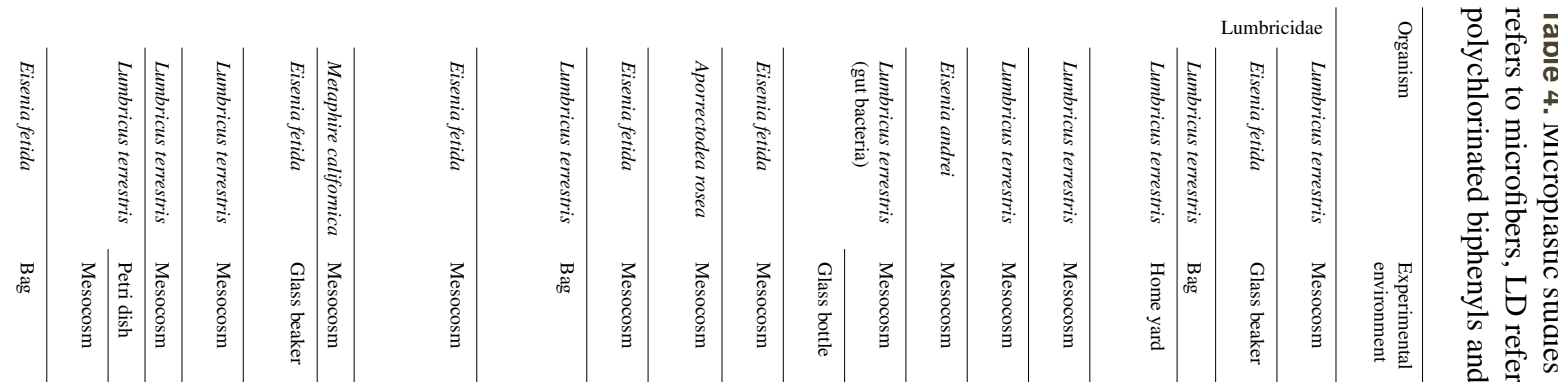

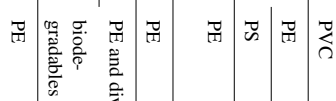

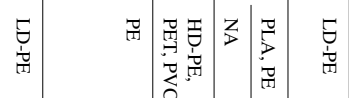

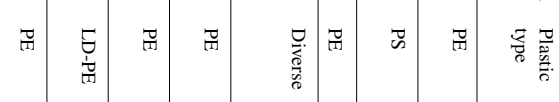

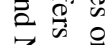

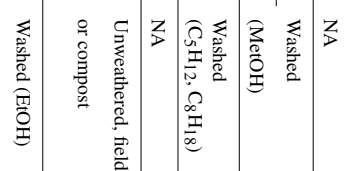

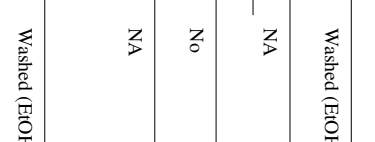

$z \quad z \quad z \quad z \quad z \quad z$

$z \quad z \quad z \quad z \quad z$

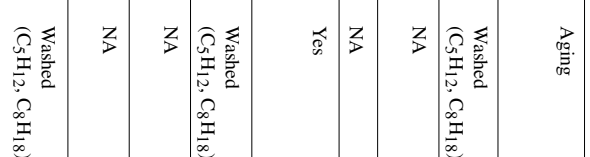

家完家

$z \quad z z \frac{2}{z} \frac{2}{2}$

$\begin{array}{lllll}8 & z & z & z & z\end{array}$

$z \quad z \quad z \quad z \quad z \quad z$

z $z$

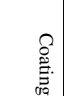

웅 के

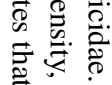

害宁宁

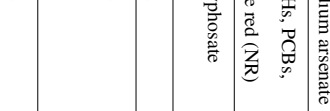

$-\quad \sigma \mid z-0 \quad 00$

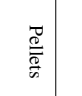

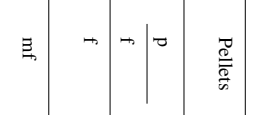

$z z \quad z \quad z \quad z z$

$z \quad z$

蛋

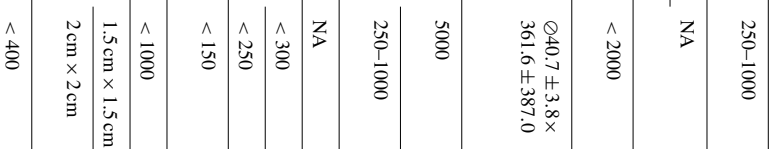

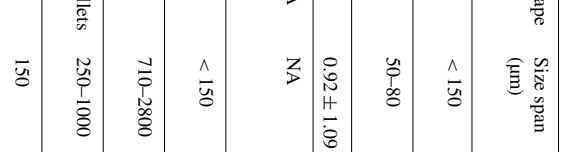

定

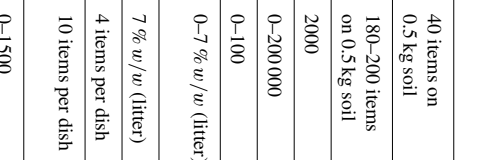

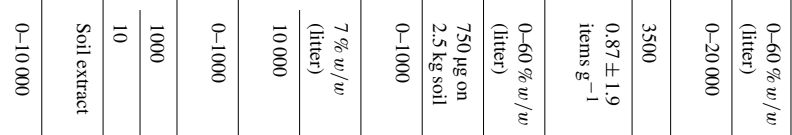

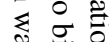

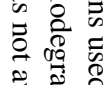

芩苛

蒙

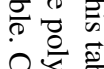

ᄋ

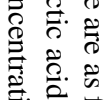

के

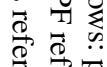

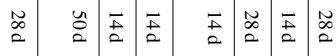

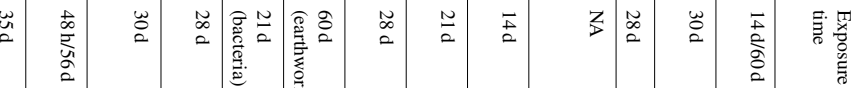

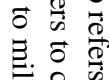

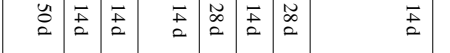

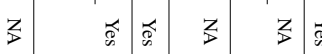

$z \quad z \quad z$

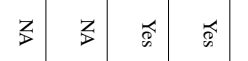

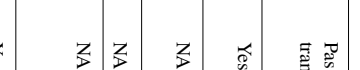

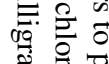

害要

क्ष.

$\checkmark$

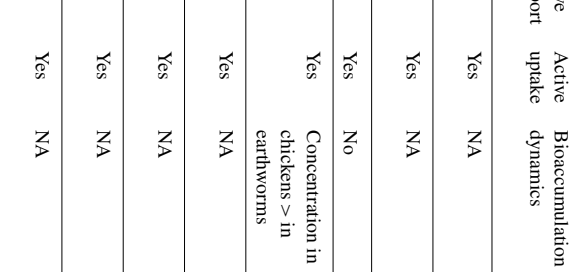

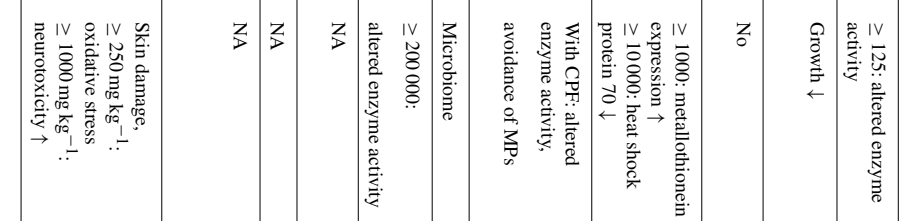
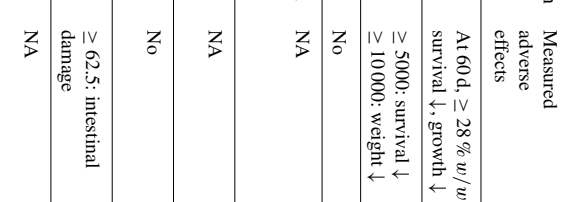

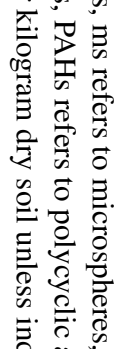

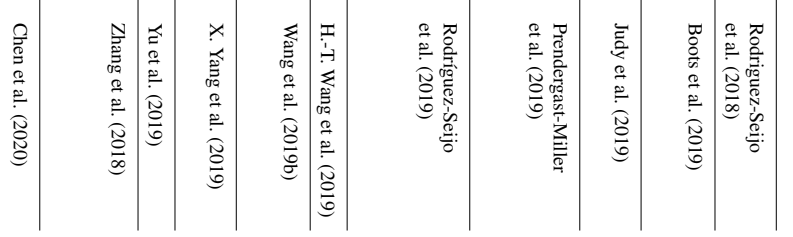
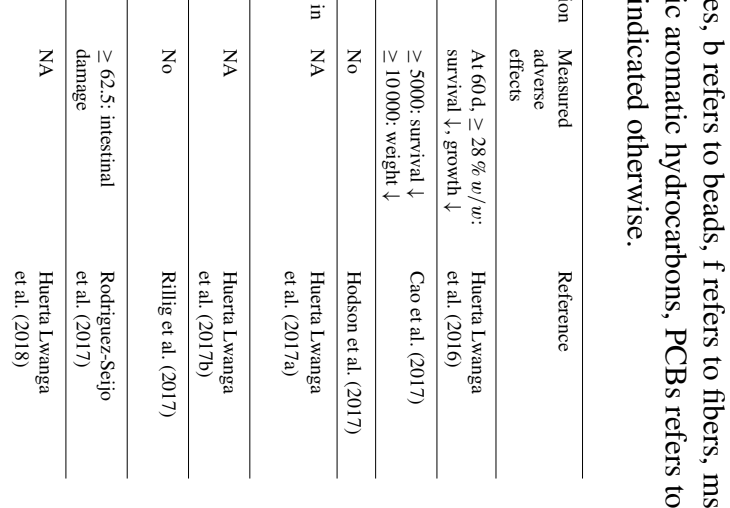


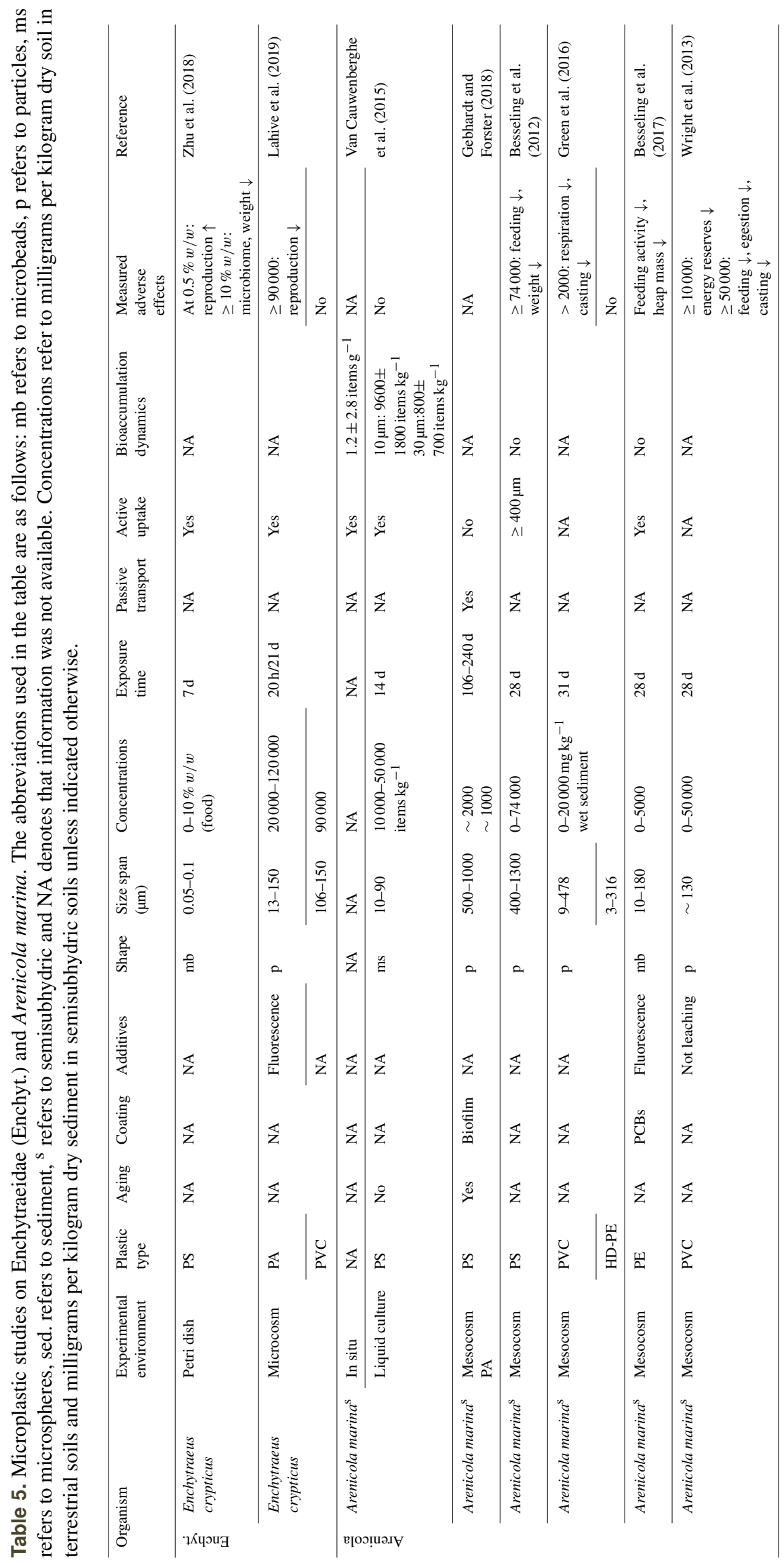


(Frey, 1971) are still lacking. When assuming in first proximity milligrams per liter solution is equal to milligrams per kilogram dry soil, the concentrations applied between 0.001 and $86.8 \mathrm{mg} \mathrm{L}^{-1}$ match lower levels of soil contamination.

Feeding studies on the phylum Rotifera with MPs are fully based on PS microbeads and model organisms of the planktonic genus Brachionus. However, these data can carefully be transferred to soil environments as soil rotifers are also aquatic organisms living in water-filled pores and water films. Different Brachionus sp. ingest microbeads $<10 \mu \mathrm{m}$ with a strong preference for particles the size of their natural food source, namely bacteria and algae from 2 to $5 \mu \mathrm{m}$ in diameter (Vadstein et al., 1993; Heerkloß and Hlawa, 1995; Baer et al., 2008; Jeong et al., 2016). The uptake appears to be selective, as fewer microbeads are incorporated compared with bacteria and algae (Vadstein et al., 1993). The egestion of particles $\leq 0.5 \mu \mathrm{m}$ is hindered compared with $6 \mu \mathrm{m}$ particles (Jeong et al., 2016). In suspension, microbeads $\leq 0.5 \mu \mathrm{m}$ cause adverse effects on fertility and life span at $\geq 0.1 \mathrm{mg} \mathrm{L}^{-1}$ as well as oxidative stress and inhibited growth at $\geq 10 \mathrm{mg} \mathrm{L}^{-1}$ (Jeong et al., 2016; Sun et al., 2019).

Terrestrial mollusks comprise snails and slugs within the class of Gastropoda. These grazers feed on bacterial biofilms, fungi and plant tissue (Parkyn and Newell, 2013). Studies on terrestrial species are sparse, but data on the benthic Littorina sp. imply passive transport and nonselective MP uptake by feeding on surfaces with contaminated feces and mucus trails from other snails (Gutow et al., 2019). With focus on benthic snails, Imhof and Laforsch (2016) found no significant influence on the growth parameters and fertility of juvenile and adult Potamopyrgus antipodarum even when a food source with $70 \% w / w$ of $5-600 \mu \mathrm{m}$ sized fragments was given (a mixture of PA, PC, PET, PS and PVC). In contrast, adverse effects were found in recent work on the terrestrial snail Achatina fulica, which showed uptake and complete gastrointestinal passage within $48 \mathrm{~h}$ with partial degradation of PET fibers (approximately $1258 \times 76 \mu \mathrm{m}$ ), but reduced excretion and food intake as well as increased oxidative stress at concentrations of $\geq 0.01, \geq 0.14$ and $\geq 0.71 \mathrm{~g} \mathrm{~kg}^{-1}$ dry soil, respectively (Song et al., 2019).

\subsection{Vertebrates}

Different taxa of the class of Amphibia have a predator function within the edaphic food web (e.g., preying on invertebrates; Hebrard et al., 1992). While no data on the reaction to soil MPs are available for the legless Gymnophiona nor for adults of the order Anura, sparse data on tadpoles of aquatic frogs suggest uptake followed by regular excretion of PS microspheres as shown for Xenopus tropicalis (Hu et al., 2016). Furthermore, no data exist on the Serpentes (snakes) and Anguidae families within the Reptilia class, which resides at the outer rim of the food web.

Within the broad field of Mammalia, studies on MP ingestion are sparse and focus on mice as a rodent model organ- ism. Feeding of mice with PS microspheres from 1 to $14 \mu \mathrm{m}$ at concentrations from $1.49 \times 10^{6}$ to $4.55 \times 10^{7}$ particles at a volume of $10 \mathrm{~mL} \mathrm{~kg}^{-1}$ body weight for 4 weeks showed no adverse effects (Stock et al., 2019). In contrast, longer exposures (6 weeks) to lower particle concentrations with the same shape and size range changed the mouse microbiome and caused metabolic and intestinal dysfunction ( $\mathrm{Lu}$ et al., 2018; Jin et al., 2019), which accompanies bioaccumulation within organs (Y.-F. Yang et al., 2019). These studies have regularly been conducted with passive feeding and exclude active foraging on perceptible plastic particles. However, the uptake via prey or feeding on contaminated roots and litter is highly probable. Further Rodentia - Cricetidae (hamsters, lemmings, voles), Bathyergidae (blesmols, mole-rats), Octodontidae as well as spermophilus (ground squirrels) and marmota (marmots) within the family of Sciuridae - have not yet been studied, as is the case for other mammalian (sub)orders like Chrysochloridae (golden moles), Cingulata (armadillos), Macroscelidea (elephant shrews), Notoryctemorphia and Peramelemorphia.

\section{Synthesis}

\subsection{Summarized observations}

Our systematic search comprised recent research on the interaction of soil organisms with MP as well as studies with a focus on feeding experiments, which were published far before people became aware of the issue that plastic poses. The numerous studies found that focused on the ingestion of MPs consistently showed active uptake by diverse soil organisms with few exceptions spread over the whole branch of invertebrates. In addition, studies on adverse effects caused by the intake of MP-contaminated food (e.g., uptake of food pellets by dung beetles) also implied the ingestion into the test organism. Distinct size preferences are observed in dung beetles, nematodes, rotifers and ants, with these organisms mainly ingesting particles that are small enough to enter the gastrointestinal tract. In contrast, active comminution by gnawing on larger particles has only been tested for a few taxa and has been confirmed for woodlice, termites, mealworms and earthworms (in the latter case, only after initial weathering).

After ingestion, MP is actively translocated until excretion or the death of the transporting organism, which has only been directly shown in experiments on earthworms. Passive transport by attachment, dragging and pushing has been investigated in a few experiments with earthworms, mites and springtails that partly worked without soil substrate and consistently showed positive results.

After exposure to MPs, a pattern of adverse effects can be seen: across various taxa, altered microbiomes, reduced motility, decreased body mass, lowered fertility and decreased life span as well as increased oxidative stress and metabolic malfunctioning occur in different combinations, 


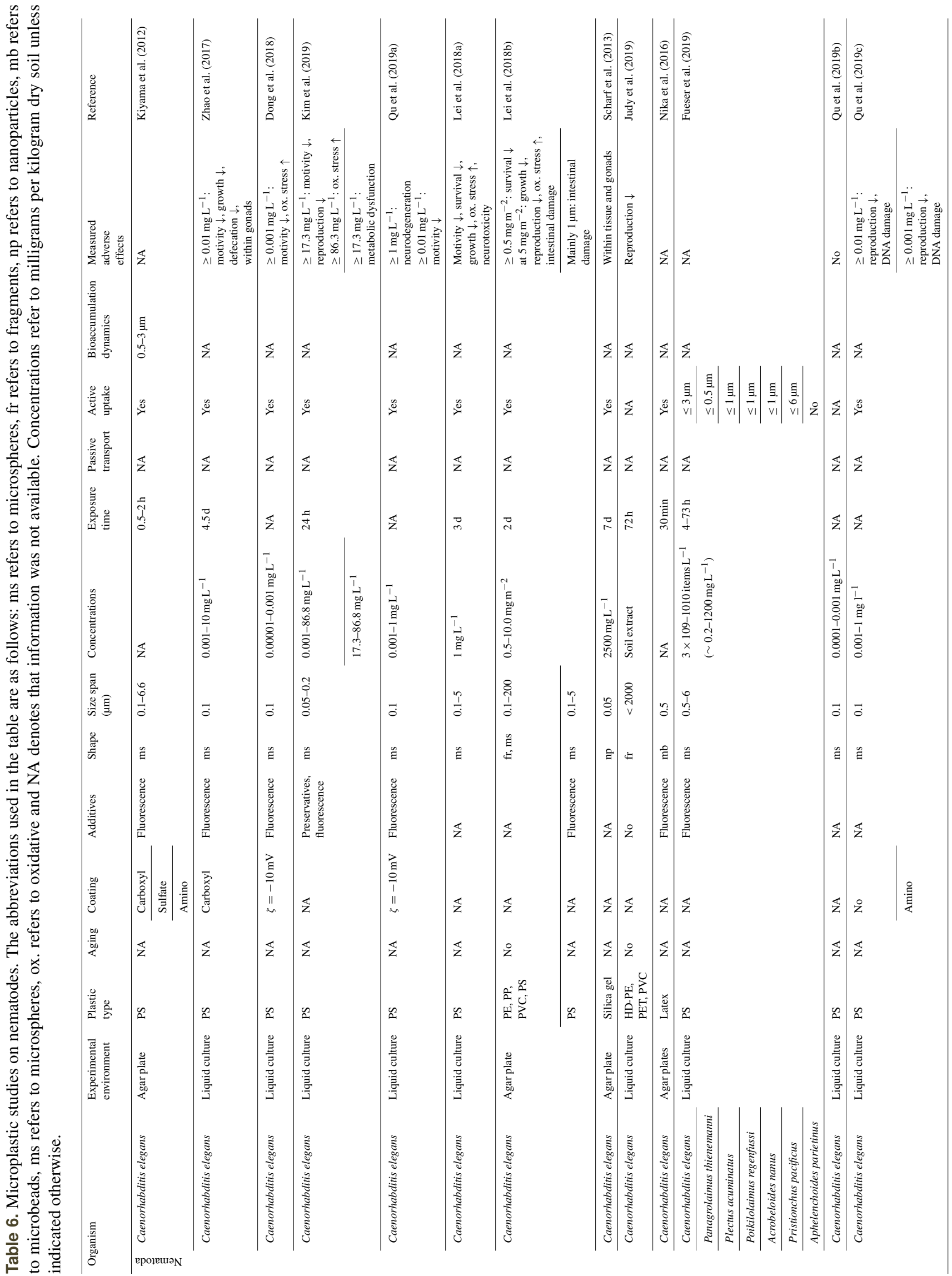




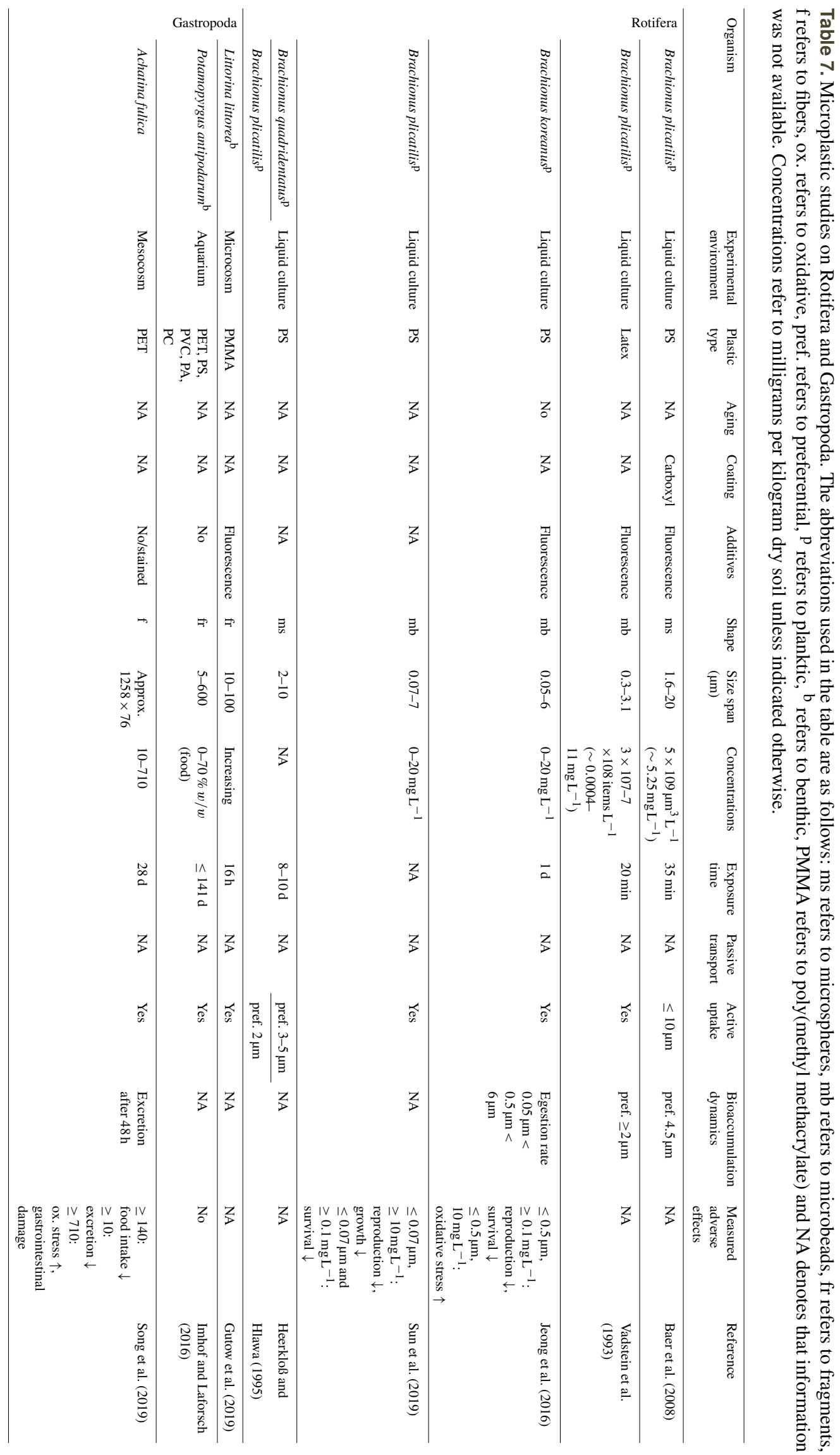




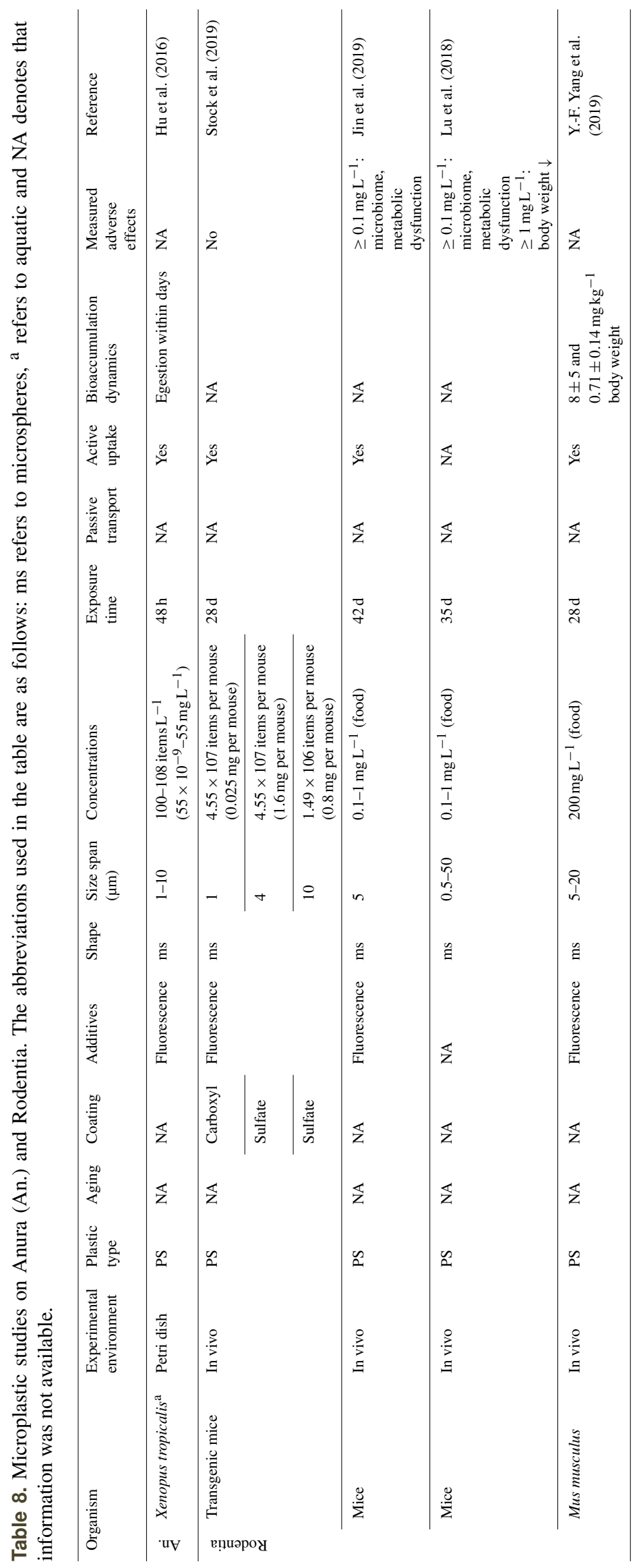


mainly due to micrometer-sized MPs in and above the whole known natural range of concentrations. For some taxa such as Nematodes, Gastropoda and Rotifera these effects appear at natural and increased MP concentrations $\left(<100 \mathrm{mg} \mathrm{kg}^{-1}\right.$ dry soil); for Collembola and Lumbricidae, these effects are found at concentrations such as those seen at highly contaminated sites ( $\geq 1000 \mathrm{mg} \mathrm{kg}^{-1}$ dry soil); and for Enchytraeidae, Arenicola marina and in further experiments with earthworms impacts are seen at implausibly high values. The data show a tendency for effects to occur at lower concentrations, when the added particles are smaller. Small-sized particles also provide the highest surface to volume ratio and, thus, the highest reactive surface per weight.

Most studies work with defined increasing MP concentrations and particle sizes in soil substrates and food sources, which can be used to determine relationships between environmental concentrations and adverse effects. However, the lack of information about intake rates, grades of accumulation and effective prey-predator transfer leads to a gap within the chain of explanation regarding the toxic effects on the soil organisms. In some experiments, the intestinal passage of MPs and sizes preferably retained within the gut have been shown, but no experiments have been able to demonstrate quantitative bioaccumulation. In contrast, quantification of the retained and egested MP particle size fractions might be biased due to gnawing and intestinal comminution as shown for woodlice, termites, mealworms, snails and earthworms.

In order to improve our understanding of processes underlying the adverse effects of MPs on soil organisms, data on ingestion rates, dwell times, biodegradation and egestion rates are important factors, e.g., to reveal bioaccumulation dynamics. However, few data exist on biodegradation (mealworms, snails and earthworms), egestion (rotifers, frogs, snails and earthworms) and remaining concentrations in the body (lugworm, mice and earthworms).

\subsection{Limitations of previous studies}

The available studies worked with items within the full size span of microplastics and nanoplastics $(\leq 5000 \mu \mathrm{m})$. Approximately $72 \%$ of the experiments used microplastic $(0.1-$ $5000 \mu \mathrm{m}), 6 \%$ used nanoplastic $(<0.1 \mu \mathrm{m}), 10 \%$ included macroplastic $(>5000 \mu \mathrm{m})$ and $12 \%$ used microplastic of undefined size. When MP $\geq 50 \mu \mathrm{m}$ was applied, mainly particles and fragments made of PE and PVC were used, whereas PS/latex microspheres were mainly applied for sizes $\leq 10 \mu \mathrm{m}$ (Table 1). The latter are readily available, highly standardized and are mostly used with fluorescent dyes and without additional functional groups, carboxylated, or, more rarely, with amino or sulfate groups. However, there are indications that the spectrum of particle type and shape used in experiments does not correspond to the properties of particles in soils. At different natural as well as agriculturally and industrially contaminated terrestrial and semisubhydric sites, fibers and fragments of PE and PP, mostly $\leq 100 \mu \mathrm{m}$, were found to be much more abundant than PVC, PET and PS items (Claessens et al., 2011; Vianello et al., 2013; Nor and Obbard, 2014; Naji et al., 2017; Zhang and Liu, 2018; J. Li et al., 2018). This is probably caused by high loads of MP fibers in discharged waste water and sewage sludge, which are used at agricultural sites worldwide (Mahon et al., 2016; X. Li et al., 2018). It is likely that shape plays an important role in the ingestion of MP items. Unfortunately, we did not find any studies that have carried out a complete classification of sampling sites according to plastic origin, size and type, which could help to evaluate the differences between former experimental and natural plastic composition to achieve the most realistic experimental conditions. Moreover, the limited knowledge on the size distribution of MPs in soils further complicates the determination of realistic concentrations for the addition of a certain particle size spectrum. All of the studies reviewed either arbitrarily set their applied concentrations or had to base them on measurements of total specific MP masses, regardless of how much of this mass is within the tested size range. This may lead to a false estimation of total adverse MP concentrations.

In contrast to particle type and shape, the documentation of chemical properties of MP samples in most of these studies is fragmentary. Some experiments explicitly mentioned that the added plastic was unweathered, whereas most studies lack information about the degree of aging, thereby implying that unweathered items were used. Only a few experiments involved the aging of MPs, but there was also no comparison to the results of natural weathering (Tsunoda et al., 2010; Gebhardt and Forster, 2018). This is in conflict with natural conditions, as plastic that remains within the soil after littering, sewage sludge application or plastic mulching shows signs of weathering, e.g., modified carbonyl indices (Andrady, 2017), whereas unweathered soil MPs might be rare. In addition, Zhang et al. (2018) showed that earthworms only actively comminute weathered bioplastics. In experiments using PS microspheres, carboxylation is often used to imitate a reduced hydrophobicity due to weathering. However, according to manufacturer information, microplastics only have a small influence on hydrophobicity.

Weathering of MP surfaces within soils comes along with biofilm growth and the adsorption of organic molecules, which could potentially affect the attractiveness or toxicity for grazers and other organisms. Such coatings were only applied in a few cases (Besseling et al., 2017; Angotti et al., 2018; Gebhardt and Forster, 2018), but they were not documented in most studies. Similarly, the type and concentration of additives such as flame retardants, antioxidants or stabilizers often remained undocumented, with the exception of fluorescent dyes, which are well mentioned. The release of additives can have a harmful effect on the test organism, as shown for aquatic environments (e Silva et al., 2016). Some studies on the ingestion of MPs by the soil mesofauna indicate that the diameter of the gastrointestinal tract is a useful upper size limit for added particles, as far as the organism 
is unable to crush them (Heerkloß and Hlawa, 1995; Holter, 2000; Holter et al., 2002; Holter and Scholtz, 2005; Baer et al., 2008; Fueser et al., 2019). However, using only ingestible particle sizes in their natural concentrations neglects the adverse effects of plastic leachates, which can also get into the soil solution and onto the mineral phase from larger particles and, thus, affect soil life.

The incubation conditions differ considerably in terms of habitats and the duration of exposure. In most studies, the exposure ranges from a few minutes to a few days in experiments with microfauna and small mesofauna and hours to several weeks in experiments with large mesofauna and macrofauna and is mainly based on excretion or reproductive cycles. Long-term studies, which are indeed difficult to carry out in mesocosms, practically do not exist. However, certain adverse effects might only establish themselves after long-term trials, as was shown for the influence of pesticides (Pelosi et al., 2015).

Some experiments were carried out in soil-free test environments, such as liquid cultures or Petri dishes with nutrient solutions or a specific food source (nematodes, rotifers, mice). Therefore, motivity is less restricted and feeding behavior can be altered compared with cultivation within soil environments. For example, the ingestion of MPs by nematodes decreases in the presence of an alternative and more natural food source, like bacteria, which can significantly reduce the bioaccumulation and, thus, the effective toxicity (Kiyama et al., 2012). This can lead to less consumption of MP in soil environments and an overestimation of the toxicity in liquid culture experiments. Moreover, all laboratory feeding experiments were carried out using only one species. Thus, the complexity of the food web in soils is excluded, and the potential accumulation from prey to predators remains unexplored.

\subsection{Directions for future research}

Most studies reviewed in this work have a pioneering role in MP research and, thus, are subject to some experimental limitations caused by an early state of knowledge. The adverse effects recently found are alarming, but they must be considered within the framework of the abovementioned restrictions. We propose the following points as part of a modus operandi for future MP research.

In past studies, particular adverse effects of MPs have only been measured for certain sizes, shapes, coatings, leachates or adsorbed substances (Tables 2-8). Experimental concentrations have been assumed randomly or derived from cumulative concentrations of one or more MP types measured in natural soils (approximately 1 to some $1000 \mathrm{mg} \mathrm{kg}^{-1}$ dry soil), regardless of size. In future experiments, the spectrum of concentrations used should be adapted to the quantities of the size spectrum that occurs within the soil. For upcoming studies on mixed contaminations, we recommend an evaluation of the overall adverse effects of PE, PP, PVC, PET, PU and PS to certain test organisms using typical MP-specific concentration ranges, sizes and shape distributions in natural soils or food samples. This requires well-structured data on the appropriate MP type, shape and size for different soils in differently contaminated areas.

Experiments on adverse effects should be applied within soil matrices to allow the interplay of plastic, natural organic and mineral matter. MPs should be weathered, as plastic in soils undergo broad environmental aging. Therefore, pre-weathering of MPs should not only be performed in climate chambers (e.g., following DIN EN ISO 4892-2/3) but should also include subsequent leaching and equilibration of additives or coatings within the soil matrix before the main experiment. Furthermore, the experimental design may consider coatings with biofilms or attractants and even particle color to regulate the preference of the test organisms.

Most detailed information about ingestion is available for dung beetles, nematodes and earthworms, and most data on adverse effects has been gathered for nematodes, earthworms, lugworms and Collembola. Future experiments should focus on a larger variety of ecologically relevant taxa like Coleoptera, Formicidae, Acari, Oniscidea, Collembola, Lumbricidae, Enchytraeidae, Nematoda and Gastropoda. It is recommended that these studies focus on uptake, accumulation and key adverse effects such as survival rate, motility, growth and fertility as well as on the stability of the intestinal microbiome. Further studies with more than one test organism are important to foster our understanding of MPs within certain food chains. Moreover, long-term experiments might reveal adverse effects that evolve slowly within populations. This may enable the assessment of the distribution and effects of MPs within the food web and the resulting long-term impact on soil ecosystems.

\section{Conclusion}

Our review of 77 studies on the impact of MPs on the soil fauna shows a considerable diversity and distribution of adverse effects within the soil tree of life. However, these effects have to be considered carefully, as many experiments did not use plastic matching the properties of plastic found within natural soils and only observed adverse effects at concentrations mirroring those of highly contaminated soils (or concentrations above these levels). To elucidate effective concentrations and properties for short- and long-term effects on soil faunal health, the most exact reproduction of plastic properties within the soil matrix and natural living conditions of the test organisms is necessary as well as a better knowledge of common concentrations and size distributions of soil MP. Therefore, for future experiments, we recommend the selection of compositions of types, shapes, sizes, concentrations, grades of weathering, leachability and coating with biofilms and other organic matter that match those expected in the habitat to be examined. Furthermore, coming 
studies should include long-term exposure and food chain experiments to get a better look at the effect of even smaller MP concentrations and their enrichment within the food web. This may provide a more effective way of assessing the impact of global MP contamination on factors such as soil biodiversity, soil carbon cycles and soil quality.

Data availability. All of the data are published within this paper and in the Supplement.

Supplement. The supplement related to this article is available online at: https://doi.org/10.5194/soil-6-245-2020-supplement.

Author contributions. FB developed the review concept, collected data and prepared the paper, except for the information on earthworms. NLvS carried out all of the work on earthworms. MK supervised the study by participating in structural discussions on the idea and concept of the paper as well as the final corrections.

Competing interests. The authors declare that they have no conflict of interest.

Acknowledgements. Many thanks to Ivica Letunic, who kindly gave us access to phyloT and made our work in face of New Year much easier. The authors will not forget to invite you for a coffee.

Review statement. This paper was edited by Fuensanta GarcíaOrenes and reviewed by Maha Deeb and three anonymous referees.

\section{References}

Allasino, M. L., Marrero, H. J., Dorado, J., and Torretta, J. P.: Scientific note: first global report of a bee nest built only with plastic, Apidologie, 50, 230-233, https://doi.org/10.1007/s13592-01900635-6, 2019.

Andrady, A. L.: The plastic in microplastics: a review, Mar. Pollut. Bull., 119, 12-22, https://doi.org/10.1016/j.marpolbul.2017.01.082, 2017.

Angotti, M. A., Rabello, A., Santiago, G., and Ribas, C.: Seed removal by ants in Brazilian savanna: optimizing fieldwork, Sociobiology, 65, 155-161, https://doi.org/10.13102/sociobiology.v65i2.1938, 2018.

Avery, S. V., Harwood, J. L., and Lloyd, D.: Quantification and Characterization of Phagocytosis in the Soil Amoeba Acanthamoeba castellanii by Flow Cytometry, Appl. Environ. Microb., 61, 1124-1132, 1995.

Baer, A., Langdon, C., Mills, S., Schulz, C., and Hamre, K.: Particle size preference, gut filling and evacuation rates of the rotifer Brachionus "Cayman" using polystyrene latex beads, Aquaculture, 282, 75-82, https://doi.org/10.1016/j.aquaculture.2008.06.020, 2008.
Bertling, J., Bertling, R., and Hamann, L.: Kunststoffe in Der Umwelt: Mikro- und Makroplastik. Ursachen, Mengen, Umweltschicksale, Wirkungen, Lösungsansätze, Empfehlungen, Fraunhofer-Gesellschaft, https://doi.org/10.24406/UMSICHTN-497117, 2018.

Besseling, E., Wegner, A., Foekema, E. M., Van Den HeuvelGreve, M. J., and Koelmans, A. A.: Effects of microplastic on fitness and PCB bioaccumulation by the lugworm Arenicola marina (L.), Environ. Sci. Technol., 47, 593-600, https://doi.org/10.1021/es302763x, 2012.

Besseling, E., Foekema, E. M., van den Heuvel-Greve, M. J., and Koelmans, A. A.: The effect of microplastic on the uptake of chemicals by the lugworm Arenicola marina (L.) under environmentally relevant exposure conditions, Environ. Sci. Technol., 51, 8795-8804, https://doi.org/10.1021/acs.est.7b02286, 2017.

Boots, B., Russell, C. W., and Green, D. S.: Effects of Microplastics in Soil Ecosystems: Above and Below Ground, Environ. Sci. Technol., 53, 11496-11506, https://doi.org/10.1021/acs.est.9b03304, 2019.

Bowers, B. and Olszewski, T. E.: Acanthamoeba discriminates internally between digestible and indigestible particles, J. Cell Biol., 97, 317-322, https://doi.org/10.1083/jcb.97.2.317, 1983.

Brandon, A. M., Gao, S.-H., Tian, R., Ning, D., Yang, S.-S., Zhou, J., Wu, W.-M., and Criddle, C. S.: Biodegradation of polyethylene and plastic mixtures in mealworms (larvae of Tenebrio molitor) and effects on the gut microbiome, Environ. Sci. Technol., 52, 6526-6533, https://doi.org/10.1021/acs.est.8b02301, 2018.

Cao, D., Wang, X., Luo, X., Liu, G., and Zheng, H.: Effects of polystyrene microplastics on the fitness of earthworms in an agricultural soil, in: IOP Conference Series: Earth and Environmental Science, Vol. 61, 3rd International Conference on Energy Materials and Environment Engineering 10-12 March 2017, Bangkok, Thailand, https://doi.org/10.1088/17551315/61/1/012148, 2017.

Chae, Y. and An, Y.-J.: Current research trends on plastic pollution and ecological impacts on the soil ecosystem: A review, Environ. Pollut., 240, 387-395, https://doi.org/10.1016/j.envpol.2018.05.008, 2018.

Chae, Y., Kim, D., Kim, S. W., and An, Y.-J.: Trophic transfer and individual impact of nano-sized polystyrene in a four-species freshwater food chain, Sci. Rep., 8, 284, https://doi.org/10.1038/s41598-017-18849-y, 2018.

Chen, Y., Liu, X., Leng, Y., and Wang, J.: Defense responses in earthworms (Eisenia fetida) exposed to low-density polyethylene microplastics in soils, Ecotox. Environ. Safe., 187, 109788, https://doi.org/10.1016/j.ecoenv.2019.109788, 2020.

Claessens, M., De Meester, S., Van Landuyt, L., De Clerck, K., and Janssen, C. R.: Occurrence and distribution of microplastics in marine sediments along the Belgian coast, Mar. Pollut. Bull., 62, 2199-2204, https://doi.org/10.1016/j.marpolbul.2011.06.030, 2011.

Darwin, C.: The formation of vegetable mould through the action of worms, with observations on their habits, John Murray, London, 1881.

De Bruyn, L. and Conacher, A. J.: The role of termites and ants in soil modification-a review, Soil Res., 28, 55-93, https://doi.org/10.1071/SR9900055, 1990.

Dong, S., Qu, M., Rui, Q., and Wang, D.: Combinational effect of titanium dioxide nanoparticles and nanopolystyrene par- 
ticles at environmentally relevant concentrations on nematode Caenorhabditis elegans, Ecotox. Environ. Safe., 161, 444-450, https://doi.org/10.1016/j.ecoenv.2018.06.021, 2018.

Elloway, E. A., Bird, R. A., Hewitt, C. J., Kelly, S. L., and Smith, S. N.: Characterization of Acanthamoeba-microsphere association by multiparameter flow cytometry and confocal microscopy, Cytom. Part A, 69, 266-272, https://doi.org/10.1002/cyto.a.20210, 2006.

e Silva, P. P. G., Nobre, C. R., Resaffe, P., Pereira, C. D. S., and Gusmão, F.: Leachate from microplastics impairs larval development in brown mussels, Water Res., 106, 364-370, https://doi.org/10.1016/j.watres.2016.10.016, 2016.

Fenchel, T.: Suspension feeding in ciliated protozoa: functional response and particle size selection, Microb. Ecol., 6, 1-11, https://doi.org/10.1007/BF02020370, 1980.

Ferris, H.: Contribution of nematodes to the structure and function of the soil food web, J. Nematol., 42, 63-67, 2010.

Frey, F.: The suitability of Acrobeloides buetschlii for ncmatological experiments, Nematologica, 17, 474-477, 1971.

Fründ, H.-C., Graefe, U., and Tischer, S.: Earthworms as bioindicators of soil quality, in: Biology of earthworms, edited by: Karaca, A., Soil Biology, Vol. 24, Springer, Berlin, Heidelberg, https://doi.org/10.1007/978-3-642-14636-7_16, 2011.

Fueser, H., Mueller, M.-T., Weiss, L., Höss, S., and Traunspurger, W.: Ingestion of microplastics by nematodes depends on feeding strategy and buccal cavity size, Environ. Pollut., 255, 113227, https://doi.org/10.1016/j.envpol.2019.113227, 2019.

Fuller, S. and Gautam, A.: A procedure for measuring microplastics using pressurized fluid extraction, Environ. Sci. Technol., 50, 5774-5780, https://doi.org/10.1021/acs.est.6b00816, 2016.

Garcés-Ordóñez, O., Castillo-Olaya, V. A., Granados-Briceño, A. F., Garcéa, L. M. B., and Díaz, L. F. E.: Marine litter and microplastic pollution on mangrove soils of the Ciénaga Grande de Santa Marta, Colombian Caribbean, Mar. Pollut. Bull., 145, 455462, https://doi.org/10.1016/j.marpolbul.2019.06.058, 2019.

Gebhardt, C. and Forster, S.: Size-selective feeding of Arenicola marina promotes long-term burial of microplastic particles in marine sediments, Environ. Pollut., 242, 1777-1786, https://doi.org/10.1016/j.envpol.2018.07.090, 2018.

Geyer, R., Jambeck, J. R., and Law, K. L.: Production, use, and fate of all plastics ever made, Sci. Adv., 3, e1700782, https://doi.org/10.1126/sciadv.1700782, 2017.

Glancey, B. M., Vander Meer, R., Glover, A., Lofgren, C., and Vinson, S.: Filtration of microparticles from liquids ingested by the red imported fire antSolenopsis invicta Buren, Insect. Soc., 28, 395-401, https://doi.org/10.1007/BF02224196, 1981.

Green, D. S., Boots, B., Sigwart, J., Jiang, S., and Rocha, C.: Effects of conventional and biodegradable microplastics on a marine ecosystem engineer (Arenicola marina) and sediment nutrient cycling, Environ. Pollut., 208, 426-434, https://doi.org/10.1016/j.envpol.2015.10.010, 2016.

Gulvik, M.: Mites (Acari) as indicators of soil biodiversity and land use monitoring: a review, Pol. J. Ecol., 55, 415-440, 2007.

Gusmão, F., Di Domenico, M., Amaral, A. C. Z., Martínez, A., Gonzalez, B. C., Worsaae, K., do Sul, J. A. I., and da Cunha Lana, P.: In situ ingestion of microfibres by meiofauna from sandy beaches, Environ. Pollut., 216, 584-590, https://doi.org/10.1016/j.envpol.2016.06.015, 2016.
Gutow, L., Bartl, K., Saborowski, R., and Beermann, J.: Gastropod pedal mucus retains microplastics and promotes the uptake of particles by marine periwinkles, Environ. Pollut., 246, 688-696, https://doi.org/10.1016/j.envpol.2018.12.097, 2019.

Hassall, M. and Rushton, S.: Feeding behaviour of terrestrial isopods in relation to plant defences and microbial activity, in: Symposia of the Zoological Society of London, Cambridge University Press, Cambridge, United Kingdom, 1984.

Hebrard, J. J., Maloiy, G. M., and Alliangana, D. M.: Notes on the habitat and diet of Afrocaecilia taitana (Amphibia: Gymnophiona), J. Herpetol., 26, 513-515, https://doi.org/10.2307/1565136, 1992.

Heerkloß, R. and Hlawa, S.: Feeding biology of two brachionid rotifers: Brachionus quadridentatus and Brachionus plicatilis, Hydrobiologia, 313, 219-221, https://doi.org/10.1007/BF00025954, 1995.

Hodson, M. E., Duffus-Hodson, C. A., Clark, A., PrendergastMiller, M. T., and Thorpe, K. L.: Plastic bag derivedmicroplastics as a vector for metal exposure in terrestrial invertebrates, Environ. Sci. Technol., 51, 4714-4721, https://doi.org/10.1021/acs.est.7b00635, 2017.

Holter, P.: Particle feeding in Aphodius dung beetles (Scarabaeidae): old hypotheses and new experimental evidence, Funct. Ecol., 14, 631-637, 2000.

Holter, P. and Scholtz, C.: Are ball-rolling (Scarabaeini, Gymnopleurini, Sisyphini) and tunnelling scarabaeine dung beetles equally choosy about the size of ingested dung particles?, Ecol. Entomol., 30, 700-705, https://doi.org/10.1111/j.03076946.2005.00746.x, 2005.

Holter, P., Scholtz, C., and Wardhaugh, K.: Dung feeding in adult scarabaeines (tunnellers and endocoprids): even large dung beetles eat small particles, Ecol. Entomol., 27, 169-176, https://doi.org/10.1046/j.1365-2311.2002.00399.x, 2002.

Hopkin, S. P.: Biology of the springtails (Insecta: Collembola), OUP Oxford, Oxford, 1997.

Hu, L., Su, L., Xue, Y., Mu, J., Zhu, J., Xu, J., and Shi, H.: Uptake, accumulation and elimination of polystyrene microspheres in tadpoles of Xenopus tropicalis, Chemosphere, 164, 611-617, https://doi.org/10.1016/j.chemosphere.2016.09.002, 2016.

Huang, Y., Liu, Q., Jia, W., Yan, C., and Wang, J.: Agricultural plastic mulching as a source of microplastics in the terrestrial environment, Environ. Pollut., 260, 114096, https://doi.org/10.1016/j.envpol.2020.114096, 2020.

Huerta Lwanga, E., Gertsen, H., Gooren, H., Peters, P., Salánki, T., van der Ploeg, M., Besseling, E., Koelmans, A. A., and Geissen, V.: Microplastics in the terrestrial ecosystem: implications for Lumbricus terrestris (Oligochaeta, Lumbricidae), Environ. Sci. Technol., 50, 2685-2691, https://doi.org/10.1021/acs.est.5b05478, 2016.

Huerta Lwanga, E., Vega, J. M., Quej, V. K., de los Angeles Chi, J., del Cid, L. S., Chi, C., Segura, G. E., Gertsen, H., Salánki, T., van der Ploeg, M., Koelmans, A. A., and Geissen, V.: Field evidence for transfer of plastic debris along a terrestrial food chain, Sci. Rep.-UK, 7, 14071, https://doi.org/10.1038/s41598-017-145882, 2017a.

Huerta Lwanga, E., Gertsen, H., Gooren, H., Peters, P., Salánki, T., van der Ploeg, M., Besseling, E., Koelmans, A. A., and Geissen, V.: Incorporation of microplastics from litter into bur- 
rows of Lumbricus terrestris, Environ. Pollut., 220, 523-531, https://doi.org/10.1016/j.envpol.2016.09.096, 2017b.

Huerta Lwanga, E., Thapa, B., Yang, X., Gertsen, H., Salánki, T., Geissen, V., and Garbeva, P.: Decay of low-density polyethylene by bacteria extracted from earthworm's guts: A potential for soil restoration, Sci. Total Environ., 624, 753-757, https://doi.org/10.1016/j.scitotenv.2017.12.144, 2018.

Hughes, L. and Westoby, M.: Effect of diaspore characteristics on removal of seeds adapted for dispersal by ants, Ecology, 73, 1300-1312, https://doi.org/10.2307/1940677, 1992.

Imhof, H. K. and Laforsch, C.: Hazardous or not - Are adult and juvenile individuals of Potamopyrgus antipodarum affected by non-buoyant microplastic particles?, Environ. Pollut., 218, 383391, https://doi.org/10.1016/j.envpol.2016.07.017, 2016.

Jambeck, J. R., Geyer, R., Wilcox, C., Siegler, T. R., Perryman, M., Andrady, A., Narayan, R., and Law, K. L.: Plastic waste inputs from land into the ocean, Science, 347, 768-771, https://doi.org/10.1126/science.1260352, 2015.

Jeong, C.-B., Won, E.-J., Kang, H.-M., Lee, M.-C., Hwang, D.S., Hwang, U.-K., Zhou, B., Souissi, S., Lee, S.-J., and Lee, J.S.: Microplastic size-dependent toxicity, oxidative stress induction, and p-JNK and p-p38 activation in the monogonont rotifer (Brachionus koreanus), Environ. Sci. Technol., 50, 8849-8857, https://doi.org/10.1021/acs.est.6b01441, 2016.

Jin, Y., Lu, L., Tu, W., Luo, T., and Fu, Z.: Impacts of polystyrene microplastic on the gut barrier, microbiota and metabolism of mice, Sci. Total Environ., 649, 308-317, https://doi.org/10.1016/j.scitotenv.2018.08.353, 2019.

Jonsson P. R.: Particle size selection, feeding rates and growth dynamics of marine planktonic oligotrichous ciliates (Ciliophora: Oligotrichina), Mar. Ecol.-Prog. Ser., 33, 265-277, 1986.

Jouquet, P., Dauber, J., Lagerlöf, J., Lavelle, P., and Lepage, M.: Soil invertebrates as ecosystem engineers: intended and accidental effects on soil and feedback loops, Appl. Soil Ecol., 32, 153-164, https://doi.org/10.1016/j.apsoil.2005.07.004, 2006.

Ju, H., Zhu, D., and Qiao, M.: Effects of polyethylene microplastics on the gut microbial community, reproduction and avoidance behaviors of the soil springtail, Folsomia candida, Environ. Pollut., 247, 890-897, https://doi.org/10.1016/j.envpol.2019.01.097, 2019.

Judy, J. D., Williams, M., Gregg, A., Oliver, D., Kumar, A., Kookana, R., and Kirby, J. K.: Microplastics in municipal mixedwaste organic outputs induce minimal short to long-term toxicity in key terrestrial biota, Environ. Pollut., 252, 522-531, https://doi.org/10.1016/j.envpol.2019.05.027, 2019.

Kale, S. K., Deshmukh, A. G., Dudhare, M. S., and Patil, V. B.: Microbial degradation of plastic: a review, J. Biochem. Technol., 6, 952-961, 2015.

Kim, H. M., Lee, D.-K., Long, N. P., Kwon, S. W., and Park, J. H.: Uptake of nanopolystyrene particles induces distinct metabolic profiles and toxic effects in Caenorhabditis elegans, Environ. Pollut., 246, 578-586, https://doi.org/10.1016/j.envpol.2018.12.043, 2019.

Kim, S. W. and An, Y.-J.: Soil microplastics inhibit the movement of springtail species, Environ. Int., 126, 699-706, https://doi.org/10.1016/j.envint.2019.02.067, 2019.

Kiyama, Y., Miyahara, K., and Ohshima, Y.: Active uptake of artificial particles in the nematode Caenorhabditis elegans, J.
Exp. Biol., 215, 1178-1183, https://doi.org/10.1242/jeb.067199, 2012.

Kokalj, A. J., Horvat, P., Skalar, T., and Kržan, A.: Plastic bag and facial cleanser derived microplastic do not affect feeding behaviour and energy reserves of terrestrial isopods, Sci. Total Environ., 615, 761-766, https://doi.org/10.1016/j.scitotenv.2017.10.020, 2018.

Korb, J.: The ecology of social evolution in termites, in: Ecology of social evolution, Springer, Berlin, Heidelberg, https://doi.org/10.1007/978-3-540-75957-7_7, 2008.

Kumar, A., Pandey, A. K., Singh, S. S., Shanker, R., and Dhawan, A.: Cellular uptake and mutagenic potential of metal oxide nanoparticles in bacterial cells, Chemosphere, 83, 1124-1132, https://doi.org/10.1016/j.chemosphere.2011.01.025, 2011.

Lahive, E., Walton, A., Horton, A. A., Spurgeon, D. J., and Svendsen, C.: Microplastic particles reduce reproduction in the terrestrial worm Enchytraeus crypticus in a soil exposure, Environ. Pollut., 255, 113174, https://doi.org/10.1016/j.envpol.2019.113174, 2019.

Lavelle, P., Decaëns, T., Aubert, M., Barot, S., Blouin, M., Bureau, F., Margerie, P., Mora, P., and Rossi, J.-P.: Soil invertebrates and ecosystem services, Eur. J. Soil Biol., 42, S3-S15, https://doi.org/10.1016/j.ejsobi.2006.10.002, 2006.

Lavin, D. P., Fredrickson, A., and Srienc, F.: Flow cytometric measurement of rates of particle uptake from dilute suspensions by a ciliated protozoan, Cytometry, 11, 875-882, https://doi.org/10.1002/cyto.990110804, 1990.

Lei, L., Liu, M., Song, Y., Lu, S., Hu, J., Cao, C., Xie, B., Shi, H., and He, D.: Polystyrene (nano) microplastics cause sizedependent neurotoxicity, oxidative damage and other adverse effects in Caenorhabditis elegans, Environ. Sci.-Nano, 5, 20092020, https://doi.org/10.1039/C9EN00473D, 2018a.

Lei, L., Wu, S., Lu, S., Liu, M., Song, Y., Fu, Z., Shi, H., RaleySusman, K. M., and He, D.: Microplastic particles cause intestinal damage and other adverse effects in zebrafish Danio rerio and nematode Caenorhabditis elegans, Sci. Total Environ., 619, 1-8, https://doi.org/10.1016/j.scitotenv.2017.11.103, 2018 b.

Lenz, M., Creffield, J. W., Evans, T. A., Kard, B., Vongkaluang, C., Sornnuwat, Y., Lee, C.-Y., Yoshimura, T., and Tsunoda, K.: Resistance of polyamide and polyethylene cable sheathings to termites in Australia, Thailand, USA, Malaysia and Japan: a comparison of four field assessment methods, Int. Biodeter. Biodegr., 66, 53-62, https://doi.org/10.1016/j.ibiod.2011.11.001, 2012.

Li, J., Zhang, H., Zhang, K., Yang, R., Li, R., and Li, Y.: Characterization, source, and retention of microplastic in sandy beaches and mangrove wetlands of the Qinzhou Bay, China, Mar. Pollut. Bull., 136, 401-406, https://doi.org/10.1016/j.marpolbul.2018.09.025, 2018.

Li, L., Zhou, Q., Yin, N., Tu, C., and Luo, Y.: Uptake and accumulation of microplastics in an edible plant, Chinese Sci. Bull., 64, 928-934, https://doi.org/10.1360/N972018-00845, 2019.

Li, X., Chen, L., Mei, Q., Dong, B., Dai, X., Ding, G., and Zeng, E. Y.: Microplastics in sewage sludge from the wastewater treatment plants in China, Water Res., 142, 75-85, https://doi.org/10.1016/j.watres.2018.05.034, 2018.

Lobelle, D. and Cunliffe, M.: Early microbial biofilm formation on marine plastic debris, Mar. Pollu. Bull., 62, 197-200, https://doi.org/10.1016/j.marpolbul.2010.10.013, 2011. 
Lu, L., Wan, Z., Luo, T., Fu, Z., and Jin, Y.: Polystyrene microplastics induce gut microbiota dysbiosis and hepatic lipid metabolism disorder in mice, Sci. Total Environ., 631, 449-458, https://doi.org/10.1016/j.scitotenv.2018.03.051, 2018.

Maaß, S., Daphi, D., Lehmann, A., and Rillig, M. C.: Transport of microplastics by two collembolan species, Environ. Pollut., 225, 456-459, https://doi.org/10.1016/j.envpol.2017.03.009, 2017.

Mahon, A. M., O'Connell, B., Healy, M. G., O'Connor, I., Officer, R., Nash, R., and Morrison, L.: Microplastics in sewage sludge: effects of treatment, Environ. Sci. Technol., 51, 810-818, https://doi.org/10.1021/acs.est.6b04048, 2016.

Monge-Nájera, J.: Ecological biogeography in the Phylum Onychophora, Biogeographica, 70, 111-123, 1994.

Naji, A., Esmaili, Z., Mason, S. A., and Vethaak, A. D.: The occurrence of microplastic contamination in littoral sediments of the Persian Gulf, Iran, Environ. Sci. Pollut. Res., 24, 20459-20468, https://doi.org/10.1007/s11356-017-9587-z, 2017.

Nika, L., Gibson, T., Konkus, R., and Karp, X.: Fluorescent beads are a versatile tool for staging Caenorhabditis elegans in different life histories, G3: Genes, Genomes, Genetics, 6, 1923-1933, https://doi.org/10.1534/g3.116.030163, 2016.

Nizzetto, L., Futter, M., and Langaas, S.: Are agricultural soils dumps for microplastics of urban origin?, Environ. Sci. Technol., 50, 10777-10779, https://doi.org/10.1021/acs.est.6b04140, 2016.

Nor, N. H. M. and Obbard, J. P.: Microplastics in Singapore's coastal mangrove ecosystems, Mar. Pollut. Bull., 79, 278-283, https://doi.org/10.1016/j.marpolbul.2013.11.025, 2014.

Oliveira, M., Ameixa, O. M., and Soares, A. M.: Are ecosystem services provided by insects "bugged" by micro (nano) plastics?, TrAC-Trend. Anal. Chem., 113, 317-320, https://doi.org/10.1016/j.trac.2019.02.018, 2019.

Parkyn, J. and Newell, D. A.: Australian land snails: a review of ecological research and conservation approaches, Molluscan Res., 33, 116-129, https://doi.org/10.1080/13235818.2013.782793, 2013.

Pass, G. and Szucsich, N. U.: 100 years of research on the Protura: many secrets still retained, Soil Organisms, 83, 309-334, 2011.

Pelosi, C., Bertrand, M., Thénard, J., and Mougin, C.: Earthworms in a 15 years agricultural trial, Appl. Soil Ecol., 88, 1-8, https://doi.org/10.1016/j.apsoil.2014.12.004, 2015.

Peng, B.-Y., Su, Y., Chen, Z., Chen, J., Zhou, X., Benbow, M. E., Criddle, C., Wu, W.-M., and Zhang, Y.: Biodegradation of Polystyrene by Dark (Tenebrio obscurus) and Yellow (Tenebrio molitor) Mealworms (Coleoptera: Tenebrionidae), Environ. Sci. Technol., 53, 5256-5265, https://doi.org/10.1021/acs.est.8b06963, 2019.

Petersen, H.: A review of collembolan ecology in ecosystem context, Acta Zoologica Fennica, 195, 111-118, 1994.

Phillips, H. R., Guerra, C. A., Bartz, M. L., Briones, M. J., Brown, G., Ferlian, O., Gongalsk, K., Krebs, J., Orgiazzi, A., Schwarz, B., Bach, E. M., Bennett, J., Brose, U., Decaëns, T., KönigRies, B., Loreau, M., Mathieu, J., Mulder, C., van der Putten, W. H., Ramirez, K. S., Rillig, M. C., Russell, D., Rutgers, M., Thakur, M. P., de Vries, F. T., Wall, D. H., Wardle, D. A., Arai, M., Ayuke, F. O., Baker, G. H., Beauséjour, R., Bedano, J. C., Birkhofer, K., Blanchart, E., Blossey, B., Bolger, T., Bradley, R. L., Callaham, M. A., Capowiez, Y., Caulfield, M. E., Choi, A., Crotty, F. V., Dávalos, A., Diaz Cosin, D. J., Dominguez,
A., Duhour, A. E., van Eekeren, N., Emmerling, C., Falco, L. B., Fernández, R., Fonte, S. J., Fragoso, C., Franco, A. L. C., Fugère, M., Fusilero, A. T., Gholami, S., Gundale, M. J., Gutiérrez López, M., Hackenberger, D. K., Hernández, L. M., Hishi, T., Holdsworth, A. R., Holmstrup, M., Hopfensperger, K. N., Huerta Lwanga, E., Huhta, V., Hurisso, T. T., Iannone III, B. V., Iordache, M., Joschko, M., Kaneko, N., Kanianska, R., Keith, A. M., Kelly, C. A., Kernecker, M. L., Klaminder, J., Koné, A. W., Kooch, Y., Kukkonen, S. T., Lalthanzara, H., Lammel, D. R., Lebedev, I. M., Li, Y., Jesus Lidon, J. B., Lincoln, N. K., Loss, S. R., Marichal, R., Matula, R., Moos, J. H., Moreno, G., Morón-Ríos, A., Muys, B., Neirynck, J., Norgrove, L., Novo, M., Nuutinen, V., Nuzzo, V., Rahman P, M., Pansu, J., Paudel, S., Pérès, G., Pérez-Camacho, L., Piñeiro, R., Ponge, J.-F., Imtiaz Rashid, M., Rebollo, S., Rodeiro-Iglesias, J., Rodríguez, M. Á., Roth, A. M., Rousseau, G. X., Rozen, A., Sayad, E., van Schaik, L., Scharenbroch, B. C., Schirrmann, M., Schmidt, O., Schröder, B., Seeber, J., Shashkov, M. P., Singh, J., Smith, S. M., Steinwandter, M., Talavera, J. A., Trigo, D., Tsukamoto, J., de Valença, A. W., Vanek, S. J., Virto, I., Wackett, A. A., Warren, M. W., Wehr, N. H., Whalen, J. K., Wironen, M. B., Wolters, V., Zenkova, I. V., Zhang, W., Cameron, E. K., and Eisenhauer, N.: Global distribution of earthworm diversity, Science, 366, 480 485, https://doi.org/10.1126/science.aax4851, 2019.

Prendergast-Miller, M. T., Katsiamides, A., Abbass, M., Sturzenbaum, S. R., Thorpe, K. L., and Hodson, M. E.: Polyester-derived microfibre impacts on the soil-dwelling earthworm Lumbricus terrestris, Environ. Pollut., 251, 453-459, https://doi.org/10.1016/j.envpol.2019.05.037, 2019.

Pulleman, M., Creamer, R., Hamer, U., Helder, J., Pelosi, C., Peres, G., and Rutgers, M.: Soil biodiversity, biological indicators and soil ecosystem services - an overview of European approaches, Curr. Opin. Env. Sust., 4, 529-538, https://doi.org/10.1016/j.cosust.2012.10.009, 2012.

Qu, M., Kong, Y., Yuan, Y., and Wang, D.: Neuronal damage induced by nanopolystyrene particles in nematode Caenorhabditis elegans, Environ. Sci.-Nano, 6, 2591-2601, https://doi.org/10.1039/C9EN00473D, 2019a.

Qu, M., Nida, A., Kong, Y., Du, H., Xiao, G., and Wang, D.: Nanopolystyrene at predicted environmental concentration enhances microcystin-LR toxicity by inducing intestinal damage in Caenorhabditis elegans, Ecotox. Environ. Safe., 183, 109568, https://doi.org/10.1016/j.ecoenv.2019.109568, 2019b.

Qu, M., Qiu, Y., Kong, Y., and Wang D.: Amino modification enhances reproductive toxicity of nanopolystyrene on gonad development and reproductive capacity in nematode Caenorhabditis elegans, Environ. Pollut., 254, 112978, https://doi.org/10.1016/j.envpol.2019.112978, 2019c.

Reddy, M. S., Basha, S., Adimurthy, S., and Ramachandraiah, G.: Description of the small plastics fragments in marine sediments along the Alang-Sosiya ship-breaking yard, India, Estuar. Coast. Shelf S., 68, 656-660, https://doi.org/10.1016/j.ecss.2006.03.018, 2006.

Rezaei, M., Riksen, M. J., Sirjani, E., Sameni, A., and Geissen, V.: Wind erosion as a driver for transport of light density microplastics, Sci. Total Environ., 669, 273-281, https://doi.org/10.1016/j.scitotenv.2019.02.382, 2019. 
Rillig, M. C.: Microplastic in terrestrial ecosystems and the soil?, Environ. Sci. Technol., 6453-6454, https://doi.org/10.1021/es302011r, 2012.

Rillig, M. C. and Bonkowski, M.: Microplastic and soil protists: a call for research, Environ. Pollut., 241, 1128-1131, https://doi.org/10.1016/j.envpol.2018.04.147, 2018.

Rillig, M. C., Ziersch, L., and Hempel, S.: Microplastic transport in soil by earthworms, Sci. Rep.-UK, 7, 1362, https://doi.org/10.1038/s41598-017-01594-7, 2017.

Rillig, M. C., Lehmann, A., de Souza Machado, A. A., and Yang, G.: Microplastic effects on plants, New Phytol., 223, 1066-1070, https://doi.org/10.1111/nph.15794, 2019.

Robins, R. and Robins, A.: The antics of ants: ants as agents of bioturbation in a midden deposit in southeast Queensland, Environ. Archaeol., 16, 151-161, https://doi.org/10.1179/174963111X13110803261010, 2011.

Rodriguez-Seijo, A., Lourenço, J., Rocha-Santos, T., Da Costa, J., Duarte, A., Vala, H., and Pereira, R.: Histopathological and molecular effects of microplastics in Eisenia andrei Bouché, Environ. Pollut., 220, 495-503, https://doi.org/10.1016/j.envpol.2016.09.092, 2017.

Rodríguez-Seijo, A., da Costa, J. P., Rocha-Santos, T., Duarte, A. C., and Pereira, R.: Oxidative stress, energy metabolism and molecular responses of earthworms (Eisenia fetida) exposed to low-density polyethylene microplastics, Environ. Sci. Pollut. R., 25, 33599-33610, https://doi.org/10.1007/s11356-018-3317z, 2018.

Rodríguez-Seijo, A., Santos, B., da Silva, E. F., Cachada, A., and Pereira, R.: Low-density polyethylene microplastics as a source and carriers of agrochemicals to soil and earthworms, Environ. Chem., 16, 8-17, https://doi.org/10.1071/EN18162, 2019.

Sánchez-Bayo, F. and Wyckhuys, K. A.: Worldwide decline of the entomofauna: A review of its drivers, Biol. Conserv., 232, 8-27, https://doi.org/10.1016/j.biocon.2019.01.020, 2019.

Scharf, A., Piechulek, A., and von Mikecz, A.: Effect of nanoparticles on the biochemical and behavioral aging phenotype of the nematode Caenorhabditis elegans, Acs Nano, 7, 10695-10703, https://doi.org/10.1021/nn403443r, 2013.

Song, Y., Cao, C., Qiu, R., Hu, J., Liu, M., Lu, S., Shi, H., Raley-Susman, K. M., and He, D.: Uptake and adverse effects of polyethylene terephthalate microplastics fibers on terrestrial snails (Achatina fulica) after soil exposure, Environ. Pollut., 250, 447-455, https://doi.org/10.1016/j.envpol.2019.04.066, 2019.

Stamatiadis, S. and Dindal, D.: Coprophilous mite communities as affected by concentration of plastic and glass particles, Exp. Appl. Acarol., 8, 1-12, https://doi.org/10.1007/BF01193377, 1990.

Stock, V., Böhmert, L., Lisicki, E., Block, R., Cara-Carmona, J., Pack, L. K., Selb, R., Lichtenstein, D., Voss, L., Henderson, C. J., Zabinsky, E., Sieg, H., Braeuning, A., and Lampen, A.: Uptake and effects of orally ingested polystyrene microplastic particles in vitro and in vivo, Arch. Toxicol., 93, 1817-1833, https://doi.org/10.1007/s00204-019-02478-7, 2019.

Sun, Y., Xu, W., Gu, Q., Chen, Y., Zhou, Q., Zhang, L., Gu, L., Huang, Y., Lyu, K., and Yang, Z.: SmallSized Microplastics Negatively Affect Rotifers: Changes in the Key Life-History Traits and Rotifer-Phaeocystis Population Dynamics, Environ. Sci. Technol., 53, 9241-9251, https://doi.org/10.1021/acs.est.9b02893, 2019.
Thompson, R. C., Swan, S. H., Moore, C. J., and Vom Saal, F. S.: Our plastic age, Philos. T. R. Soc. B, 364, 1973-1976, https://doi.org/10.1098/rstb.2009.0054, 2009.

Tsunoda, K., Rosenblat, G., and Dohi, K.: Laboratory evaluation of the resistance of plastics to the subterranean termite Coptotermes formosanus (Blattodea: Rhinotermitidae), Int. Biodeter. Biodegr., 64, 232-237, https://doi.org/10.1016/j.ibiod.2009.12.008, 2010.

Vadstein, O., Øie, G., and Olsen, Y.: Particle size dependent feeding by the rotifer Brachionus plicatilis, Hydrobiologia, 255, 261267, https://doi.org/10.1007/BF00025847, 1993.

Van Cauwenberghe, L., Claessens, M., Vandegehuchte, M. B., and Janssen, C. R.: Microplastics are taken up by mussels (Mytilus edulis) and lugworms (Arenicola marina) living in natural habitats, Environ. Pollut., 199, 10-17, https://doi.org/10.1016/j.envpol.2015.01.008, 2015.

van Gestel, C. A. and Selonen, S.: Ecotoxicological effects of microplastics in soil: Comments on the paper by Zhu et al. (2018) "Exposure of soil collembolans to microplastics perturbs their gut microbiota and alters their isotopic composition", Soil Biology \& Biochemistry 116, 302-310, Soil Biol. Biochem., 124, 116-117, https://doi.org/10.1016/j.soilbio.2018.05.032, 2018.

van Gestel, C. A., Loureiro, S., and Zidar: Terrestrial isopods as model organisms in soil ecotoxicology: a review, ZooKeys, 801, 127-162, https://doi.org/10.3897/zookeys.801.21970, 2018.

Vianello, A., Boldrin, A., Guerriero, P., Moschino, V., Rella, R., Sturaro, A., and Da Ros, L.: Microplastic particles in sediments of Lagoon of Venice, Italy: First observations on occurrence, spatial patterns and identification, Estuar. Coast. Shelf S., 130, 5461, https://doi.org/10.1016/j.ecss.2013.03.022, 2013.

Vogel, G., Thilo, L., Schwarz, H., and Steinhart, R.: Mechanism of phagocytosis in Dictyostelium discoideum: phagocytosis is mediated by different recognition sites as disclosed by mutants with altered phagocytotic properties, J. Cell Biol., 86, 456-465, https://doi.org/10.1083/jcb.86.2.456, 1980.

Wang, H.-T., Ding, J., Xiong, C., Zhu, D., Li, G., Jia, X.-Y., Zhu, Y.-G., and Xue, X.-M.: Exposure to microplastics lowers arsenic accumulation and alters gut bacterial communities of earthworm Metaphire californica, Environ. Pollut., 251, 110-116, https://doi.org/10.1016/j.envpol.2019.04.054, 2019.

Wang, J., Liu, X., Li, Y., Powell, T., Wang, X., Wang, G., and Zhang, P.: Microplastics as contaminants in the soil environment: A mini-review, Sci. Total Environ., 691, 848-857, https://doi.org/10.1016/j.scitotenv.2019.07.209, 2019a.

Wang, J., Coffin, S., Sun, C., Schlenk, D., and Gan, J.: Negligible effects of microplastics on animal fitness and HOC bioaccumulation in earthworm Eisenia fetida in soil, Environ. Pollut., 249, 776-784, https://doi.org/10.1016/j.envpol.2019.03.102, $2019 \mathrm{~b}$.

Warburg, M. R.: Isopods and their terrestrial environment, in: Advances in ecological research, Elsevier, Academic Press Inc., London, https://doi.org/10.1016/S0065-2504(08)60246-9, 1987.

Weisman, R. A. and Korn, E. D.: Phagocytosis of latex beads by Acanthamoeba. I. Biochemical properties, Biochemistry, 6, 485497, https://doi.org/10.1021/bi00854a017, 1967.

Weithmann, N., Möller, J. N., Löder, M. G., Piehl, S., Laforsch, C., and Freitag, R.: Organic fertilizer as a vehicle for the entry of microplastic into the environment, Sci. Adv., 4, eaap8060, https://doi.org/10.1126/sciadv.aap8060, 2018. 
Westheide, W. and Rieger, R.: Spezielle Zoologie. 1. Einzeller und Wirbellose Tiere, Gustav Fischer, Heidelberg, 1996.

Wood, C. T. and Zimmer, M.: Can terrestrial isopods (Isopoda: Oniscidea) make use of biodegradable plastics?, Appl. Soil Ecol., 77, 72-79, https://doi.org/10.1016/j.apsoil.2014.01.009, 2014.

Wright, S. L., Rowe, D., Thompson, R. C., and Galloway, T. S.: Microplastic ingestion decreases energy reserves in marine worms, Curr. Biol., 23, R1031-R1033, https://doi.org/10.1016/j.cub.2013.10.068, 2013.

Yang, S.-S., Brandon, A. M., Flanagan, J. C. A., Yang, J., Ning, D., Cai, S.-Y., Fan, H.-Q., Wang, Z.-Y., Ren, J., Benbow, E., Ren, N.-Q., Waymouth, R. M., Zhou, J., Criddle, C. S., and Wu, W.-M.: Biodegradation of polystyrene wastes in yellow mealworms (larvae of Tenebrio molitor Linnaeus): Factors affecting biodegradation rates and the ability of polystyrene-fed larvae to complete their life cycle, Chemosphere, 191, 979-989, https://doi.org/10.1016/j.chemosphere.2017.10.117, 2018.

Yang, X., Lwanga, E. H., Bemani, A., Gertsen, H., Salanki, T., Guo, X., Fu, H., Xue, S., Ritsema, C., and Geissen, V.: Biogenic transport of glyphosate in the presence of LDPE microplastics: A mesocosm experiment, Environ. Pollut., 245, 829-835, https://doi.org/10.1016/j.envpol.2018.11.044, 2019.

Yang, Y., Yang, J., Wu, W.-M., Zhao, J., Song, Y., Gao, L., Yang, R., and Jiang, L.: Biodegradation and mineralization of polystyrene by plastic-eating mealworms: Part 1 . Chemical and physical characterization and isotopic tests, Environ. Sci. Technol., 49, 12080-12086, https://doi.org/10.1021/acs.est.5b02661, 2015.

Yang, Y.-F., Chen, C.-Y., Lu, T.-H., and Liao, C.-M.: Toxicity-based toxicokinetic/toxicodynamic assessment for bioaccumulation of polystyrene microplastics in mice, J. Hazard. Mater., 366, 703713, https://doi.org/10.1016/j.jhazmat.2018.12.048, 2019.

Yeates, G. W.: Nematodes in ecological webs, eLS, https://doi.org/10.1002/9780470015902.a0021913, 2001.

Yu, M., Van Der Ploeg, M., Lwanga, E. H., Yang, X., Zhang, S., Ma, X., Ritsema, C. J., and Geissen, V.: Leaching of microplastics by preferential flow in earthworm (Lumbricus terrestris) burrows, Environ. Chem., 16, 31-40, https://doi.org/10.1071/EN18161, 2019.
Zhang, G. and Liu, Y.: The distribution of microplastics in soil aggregate fractions in southwestern China, Sci. Total Environ., 642, 12-20, https://doi.org/10.1016/j.scitotenv.2018.06.004, 2018.

Zhang, L., Sintim, H. Y., Bary, A. I., Hayes, D. G., Wadsworth, L. C., Anunciado, M. B., and Flury, M.: Interaction of Lumbricus terrestris with macroscopic polyethylene and biodegradable plastic mulch, Sci. Total Environ., 635, 1600-1608, https://doi.org/10.1016/j.scitotenv.2018.04.054, 2018.

Zhang, Y., Gao, T., Kang, S., and Sillanpää, M.: Importance of atmospheric transport for microplastics deposited in remote areas, Environ. Pollut., 254, 112953, https://doi.org/10.1016/j.envpol.2019.07.121, 2019.

Zhang, Z.-Q.: Animal biodiversity: an update of classification and diversity in 2013, Zootaxa, 3703, 5-11, https://doi.org/10.11646/zootaxa.3703.1.3, 2013.

Zhao, L., Qu, M., Wong, G., and Wang, D.: Transgenerational toxicity of nanopolystyrene particles in the range of $\mathrm{m} \mathrm{g} \mathrm{L}^{-1}$ in the nematode Caenorhabditis elegans, Environ. Sci.-Nano, 4, 23562366, https://doi.org/10.1039/C7EN00707H, 2017.

Zhu, B.-K., Fang, Y.-M., Zhu, D., Christie, P., Ke, X., and Zhu, Y.-G.: Exposure to nanoplastics disturbs the gut microbiome in the soil oligochaete Enchytraeus crypticus, Environ. Pollut., 239, 408-415, https://doi.org/10.1016/j.envpol.2018.04.017, 2018.

Zhu, D., Bi, Q.-F., Xiang, Q., Chen, Q.-L., Christie, P., Ke, X., Wu, L.-H., and Zhu, Y.-G.: Trophic predator-prey relationships promote transport of microplastics compared with the single Hypoaspis aculeifer and Folsomia candida, Environ. Pollut., 235, 150-154, https://doi.org/10.1016/j.envpol.2017.12.058, 2018a.

Zhu, D., Chen, Q. L., An, X. L., Yang, X. R., Christie, P., Ke, X., Wu, L.-H. and Zhu, Y. G.: Exposure of soil collembolans to microplastics perturbs their gut microbiota and alters their isotopic composition, Soil Biol. Biochem., 116, 302-310, https://doi.org/10.1016/j.soilbio.2017.10.027, 2018b. 